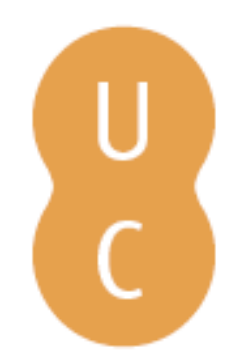

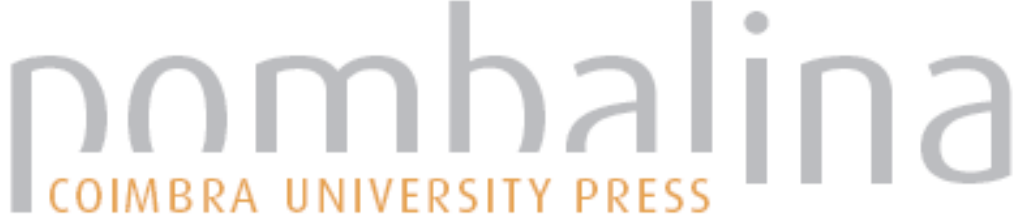

\section{Bases de dados de perfis de ADN}

Autor(es): $\quad$ Corte-Real, Francisco

Publicado por: Imprensa da Universidade de Coimbra

URL

persistente: URI:http://hdl.handle.net/10316.2/38508

DOI: $\quad$ DOI:http://dx.doi.org/10.14195/978-989-26-0957-7_6

Accessed : $\quad$ 26-Apr-2023 11:56:32

A navegação consulta e descarregamento dos títulos inseridos nas Bibliotecas Digitais UC Digitalis, UC Pombalina e UC Impactum, pressupõem a aceitação plena e sem reservas dos Termos e Condições de Uso destas Bibliotecas Digitais, disponíveis em https://digitalis.uc.pt/pt-pt/termos.

Conforme exposto nos referidos Termos e Condições de Uso, o descarregamento de títulos de acesso restrito requer uma licença válida de autorização devendo o utilizador aceder ao(s) documento(s) a partir de um endereço de IP da instituição detentora da supramencionada licença.

Ao utilizador é apenas permitido o descarregamento para uso pessoal, pelo que o emprego do(s) título(s) descarregado(s) para outro fim, designadamente comercial, carece de autorização do respetivo autor ou editor da obra.

Na medida em que todas as obras da UC Digitalis se encontram protegidas pelo Código do Direito de Autor e Direitos Conexos e demais legislação aplicável, toda a cópia, parcial ou total, deste documento, nos casos em que é legalmente admitida, deverá conter ou fazer-se acompanhar por este aviso.

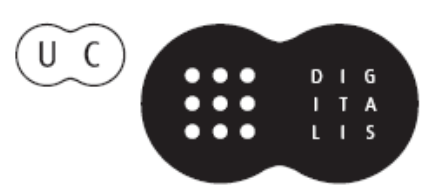




\section{PRINCÍPIOS}

\section{DE GENÉTICA}

\section{FORENSE}

FRANCISCO CORTE-REAL DUARTE NUNO VIEIRA

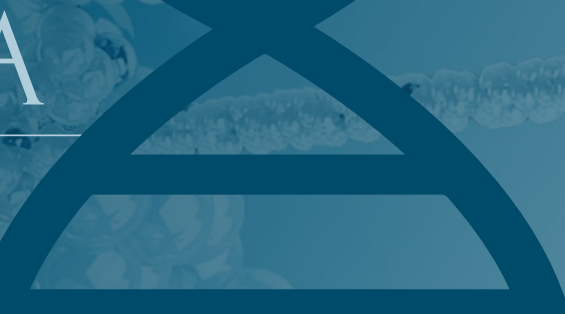

c)
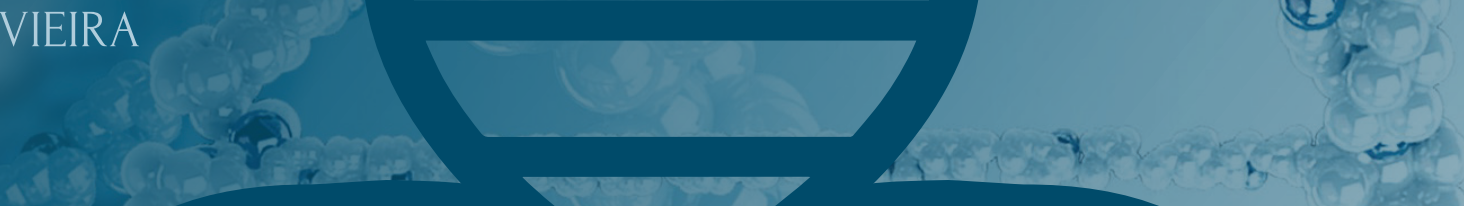

(4)

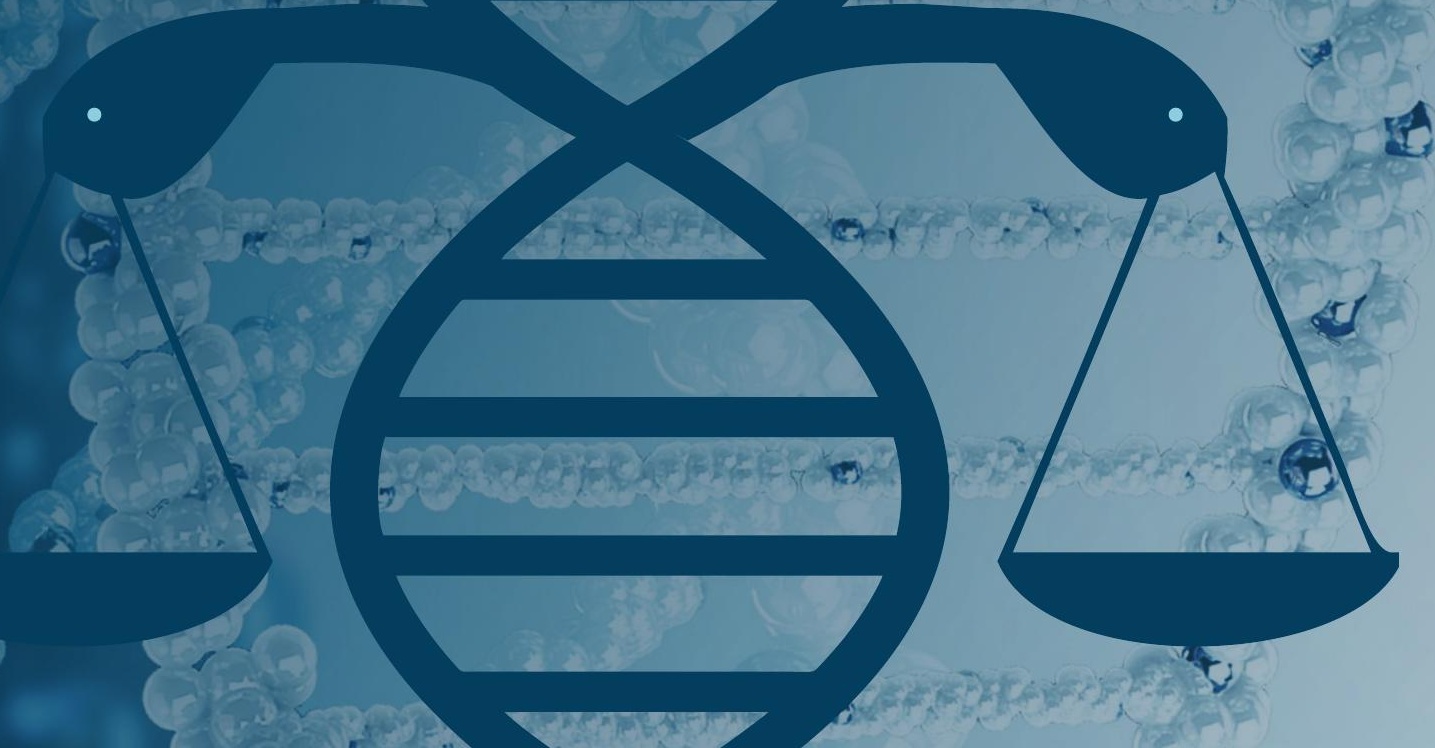

min $2(5)$

Exar. 
Capítulo 6 BASE DE DADOS DE PERFIS DE ADN

\section{Francisco Corte-Real}

Professor da Faculdade de Medicina da Universidade de Coimbra Instituto Nacional de Medicina Legal e Ciências Forenses, I. P. DOI | HTTP://DX.DOI.ORG/10.14195/978-989-26-0957-7_6 


\section{RESUMO}

Decorridos seis anos desde a publicação da lei que aprovou a criação da base de dados de perfis de ADN e quatro anos desde a inserção do primeiro perfil importaria fazer uma análise retrospectiva sobre o processo que levou à publicação da Lei n. ${ }^{\circ}$ 5/2008, de 12 de Fevereiro, à entrada em funcionamento da base de dados, bem como descrever a situação actual. Assim, neste texto é feita uma descrição das iniciativas que originaram a publicação da lei e dos aspectos que suscitaram mais controvérsia. São apresentadas as especificidades da base de dados Portuguesa, comparando-a, de forma sucinta, com algumas outras bases de dados europeias, descrevendo-se os problemas actualmente existentes. São abordados os pressupostos previstos para a cooperação internacional nesta matéria, tal como os principais desafios que se perspectivam.

\section{PALAVRAS-CHAVE}

Base de dados; ADN; legislação; cooperação internacional.

\section{ABSTRACT}

Six years after the publication of the law that approved the creation of the DNA profiles database and four years after the insertion of the first profile it's important to do an analysis of the process that led to the publication of Law No. 5/2008, of 12 February, the entry into operation of the database, as well as describing the current situation. Thus, this text is a brief description of the initiatives that led to the publication of the law and the issues that prompted the most controversy. The specificities of the Portuguese database are presented succinctly, comparing it with some other European databases, describing the existing problems. The assumptions provided for international cooperation in this area are discussed, as the main challenges that lie ahead.

\section{KEYWORDS}

Database; DNA; legislation; international cooperation. 


\section{INTRODUÇÃO}

Acompanhando o avanço científico e tecnológico característico do final do século XX, também a Genética Forense sofreu, nas duas últimas décadas, um desenvolvimento muito significativo. Esse desenvolvimento permitiu não apenas uma maior sensibilidade nos resultados analíticos como também uma diversificação do tipo de marcadores genéticos à disposição da investigação. A vulgarização internacional das análises genéticas com fins forenses originou um elevado volume de informação, cuja comparação pode ser pertinente para, por exemplo, se saber se o mesmo indivíduo está implicado em diferentes crimes ou para se identificar o cadáver de uma pessoa desaparecida. Tal facto levou a que muitos países instituíssem bases de dados de perfis de ADN a partir de 1995.

Este objectivo foi oficializado na Europa através da Resolução do Conselho de 9 de Junho de 1997, relativa ao estabelecimento de bases de dados nacionais de ADN, e da Resolução do Conselho de 25 de Junho de 2001, relativa à partilha de perfis de ADN entre os diversos estados membros. A necessidade de partilha de informação entre os diferentes países foi protocolada pelo Acordo de Prüm e, posteriormente,

1 Celebrado na cidade alemã de Prüm, a 27 de Maio de 2005, entre o Reino da Bélgica, a Alemanha, a Espanha, a França, o Luxemburgo, os Países Baixos e a Áustria, com vista a aprofundar a cooperação policial transfronteiras nomeadamente nos domínios da luta contra o terrorismo, a criminalidade organizada e a imigração ilegal e lançando as bases para uma cooperação avançada entre estados membros da União Europeia. Nos termos do Acordo de Prüm, o intercâmbio de informações abrange, para efeitos de prevenção e investigação de infracções penais e de manutenção da ordem e segurança públicas, as matérias relativas, nomeadamente, aos perfis de ADN, aos dados dactiloscópicos, a outros dados pessoais com aqueles relacionados, e aos dados relativos aos registos de matrícula de veículos. pela Decisão do Conselho 2008/615/JAI, em 23 de Junho de 2008, referente ao aprofundamento da cooperação transfronteiras, em particular no domínio da luta contra o terrorismo e a criminalidade transfronteiras.

Em Portugal, até à criação da base de dados de perfis de ADN, a comparação entre diferentes processos só era possível em casos isolados, mediante uma indicação expressa da autoridade judiciária. Se ocorresse um determinado crime e se conseguisse colher um vestígio biológico no local, só após a presença de um suspeito ou arguido se poderia fazer um estudo comparativo entre o perfil de ADN do vestígio e o perfil de uma amostra conhecida. A base de dados de perfis de ADN veio permitir a comparação entre o perfil do vestígio e os perfis já existentes nessa base, possibilitando a identificação da pessoa envolvida ou a obtenção de dados informativos relativos à participação noutras situações anteriores. Este aspecto é extremamente relevante no caso de crimes com tendência repetitiva, em que possa existir uma probabilidade significativa da perpretação de um novo crime, o que pode acontecer, por exemplo, nos homicídios dolosos ou nos crimes de natureza sexual.

O nosso País possui, desde há muito, as condições técnicas e científicas necessárias ao estabelecimento de uma base de dados de perfis de ADN. As metodologias seguidas por vários laboratórios Portugueses encontram-se harmonizadas com as estabelecidas em muitos outros laboratórios estrangeiros. Os seus elementos pertencem a sociedades científicas comuns (nomeadamente a Sociedade Internacional de Genética Forense) que, periodicamente, promovem reuniões, congressos e exercícios de controlo de qualidade. Tal 
facto, associado à escolha dos mesmos marcadores genéticos na constituição de uma base de dados, é extremamente importante para que seja possível a troca de informações entre os vários países, dada a actual fácil mobilidade de pessoas, designadamente no espaço Europeu.

\section{PROCESSO LEGISLATIVO}

No ano 2000 foi criado o Instituto Nacional de Medicina Legal (INML)2, resultante da fusão dos Institutos de Medicina Legal de Lisboa, Porto e Coimbra. Nesse mesmo ano, considerando o facto de que muitas amostras obtidas em locais de crime não eram sujeitas a comparação por inexistência de qualquer suspeito ou arguido, bem como a criação de bases dados de perfis de ADN em diversos países europeus funcionando com sucesso, este Instituto defendeu publicamente a criação em Portugal de uma base de dados de perfis de ADN.

Um levantamento à data realizado, considerando apenas os casos analisados no INML, revelou que aproximadamente $20 \%$ dos perfis obtidos de amostras colhidas no âmbito de investigações criminais nunca foram identificados, pela circunstância de não ter sido presente qualquer suspeito ou arguido para comparação ou, no caso de tal ter ocorrido, pelo facto de o perfil não ter coincidido com o(s) suspeito(s) ou arguido(s) presente(s) a exame. Apesar de este valor não representar a totalidade nacional, pois duas instituições realizam

2 Pelo Decreto-Lei n. ${ }^{\circ}$ 146/2000, de 18 de Julho. Passou a ser designado por Instituto Nacional de Medicina Legal e Ciências Forenses, I.P., a partir da publicação do Decreto-Lei n. ${ }^{\circ}$ 166/2012, de 31 de Julho. perícias oficiais na área da criminalística biológi$\mathrm{ca}^{3}$, evidencia bem o quanto uma base de dados poderia apoiar os processos de investigação criminal. Mesmo que essa proporção de amostras não identificadas fosse substancialmente inferior justificar-se-ia a criação de uma base de dados de perfis de ADN em Portugal.

A circunstância de haver uma Resolução do Conselho da Europa de 9 de Junho de 19974, instando os estados membros a estabelecerem bases de dados de perfis de ADN, constituiu também um argumento a favor da criação de uma base de dados no nosso País. Esta resolução aconselhava os estados membros a criar as suas bases de dados de acordo com os mesmos parâmetros e de forma compatível. Salientou ainda, entre outros aspectos, que a possibilidade de partilha de dados se deveria limitar à parte não codificante do ADN, considerada como não contendo informação relativa a características hereditárias específicas.

A Resolução do Conselho da União Europeia de 25 de Junho de 2001 relativa ao intercâmbio de resultados de análises de $A D N^{5}$ reforça a exigência de os estados membros limitarem a análise do ADN às "zonas cromossómicas sem expressão genética, ou seja, que, ao que se sabe, não contenham informação sobre características hereditárias específicas". Acrescenta ainda a recomendação da cessação da utilização de marcadores genéticos em que venha a ser possível a obtenção de informação

3 Instituto Nacional de Medicina Legal e Laboratório de Polícia Científica da Polícia Judiciária.

4 Resolução 97/C 193/02, publicada no Jornal Oficial das Comunidades Europeias: N. ${ }^{\circ} \mathrm{C} 193$, de 24/06/1997, pp. 00020003.

5 Resolução 2001/C 187/01, publicada no Jornal Oficial das Comunidades Europeias: N. ${ }^{\circ}$ C 187, 03/07/2001, pp. 0001-0004. 
sobre tais características. A Resolução propõe um conjunto de sete marcadores para inclusão nas bases de dados nacionais ${ }^{6}$.

Em 19 de Junho de 2001 o INML organizou, na Universidade de Aveiro, o primeiro seminário sobre bases de dados genéticos, intitulado "Genética ao serviço da Justiça", que contou com a presença de inúmeras personalidades oriundas não apenas do campo científico, mas também das áreas jurídica, ética e sociológica. Não obstante a inexistência de consensos sobre a matéria, o então Ministro da Justiça ${ }^{7}$, como também o Secretário de Estado da Justiça ${ }^{8}$, salientaram a intenção do Governo no sentido de se avançar para a criação de uma base de dados genéticos em Portugal.

Dezenas de intervenções públicas, palestras, reuniões e seminários ocorreram nos anos que se seguiram, tendo este tema merecido um particular destaque por parte da comunicação social.

Em 2003, a Polícia Judiciária e o INML apresentaram projectos de lei ao Ministério da justiça, com vista à criação de uma base de dados de perfis de ADN.

Contudo, apenas em 2005 e pela primeira vez, o Programa do XVII Governo Constitucional estabeleceu a intenção de criar uma base de dados em Portugal, referindo o seguinte: "... será criada uma base geral de dados genéticos para fins de identificação civil, que servirá igualmente fins de investigação criminal (assegurando-se que a respectiva custódia não competirá a órgão de polícia criminal)". Conhecendo-se a autoria do Programa do Governo nesta área, não se

\footnotetext{
6 Designados por "European Standard Set".

7 Dr. António Costa.

8 Dr. Diogo Lacerda Machado.
}

estranhou a intenção da criação de uma base de dados geral. Contudo, várias foram as vozes críticas que se levantaram, a nível nacional e internacional, questionando a necessidade, a capacidade e as condições financeiras do País para ter uma base de dados que incluísse a generalidade da população Portuguesa. No entanto, o Governo apressou-se a esclarecer, por intermédio do então Secretário de Estado da Justiça ${ }^{9}$, que se pretendia uma base de dados tendencialmente geral, construída de uma forma faseada e gradual. O segundo pressuposto referido no Programa do Governo estabeleceu que a custódia da base de dados não competiria a órgão de polícia criminal, sem qualquer outra referência, designadamente quanto a motivos para tal condição ou quanto à entidade que tutelaria a base de dados.

Por despacho do Ministro da Justiça ${ }^{10}$, de 19 de Janeiro de $2006^{11}$, foi criada uma comissão com a incumbência de apresentar até ao final desse ano uma proposta de lei que permitisse a criação da base de dados de perfis de ADN. No que se refere à metodologia proposta e com o intuito de clarificar a interpretação do previsto no Programa do Governo foi estabelecido que, na perspectiva da progressiva e gradual generalização da base de dados, a proposta deveria perspectivar o seguinte:

a) Constituição e funcionamento de uma base de dados genéticos com fins de investigação criminal;

9 Dr. Tiago Silveira.

10 Dr. Alberto Costa.

11 Publicado em Diário da República, 2 a $^{\text {série, n. }}{ }^{\circ} 24$, em 2 de Fevereiro de 2006. 
b) Constituição e funcionamento de uma base de dados genéticos com fins de identificação civil.

A comissão foi constituída por um representante do Ministro da Justiça' ${ }^{12}$, um representante do Conselho Nacional de Medicina Legal'13, um representante do Conselho Nacional de Ética e Ciências da Vida ${ }^{14}$, uma representante do Laboratório de Polícia Científica (LPC) da Polícia Judiciária ${ }^{15}$, uma representante do Centro de Direito Biomédico da Faculdade de Direito da Universidade de Coimbra ${ }^{16}$ e um representante do $\mathrm{INML}^{17}$, que coordenou. Apesar de o despacho ministerial que criou a comissão ter previsto a presença de um elemento da Comissão Nacional de Protecção de Dados, esta entidade entendeu não indicar representante pelo facto de ter de vir a pronunciar-se posteriormente, após a elaboração da proposta.

Uma das questões prévias levantadas referiu-se à aplicabilidade, neste âmbito, da Lei n. ${ }^{\circ}$ 12/2005, de 26 de Janeiro, relativa a informação genética pessoal e informação de saúde, dado que o seu artigo $1 .^{\circ}$ estabelece que a referida lei "define o conceito de informação de saúde e de informação genética, a circulação de informação e a intervenção sobre o genoma humano no sistema de saúde, bem como as regras para a colheita e conservação de produtos biológicos para efeitos de testes genéticos ou de investigação". Apesar de diversas normas e pressupostos da referida

\footnotetext{
12 Dr. Diogo Lacerda Machado.

13 Prof. Doutor André Pereira.

14 Prof. Doutor Jorge Soares.

$15 \mathrm{Dr}^{\mathrm{a}}$. Saudade Nunes.

16 Profa $^{a}$. Doutora Helena Moniz.

17 O autor do presente capítulo.
}

lei poderem ser aplicáveis às perícias de genética forense, as especificidades de uma base de dados com fins forenses bem como a multiplicidade de questões próprias desta área justificavam a aprovação de uma lei nesta matéria. Esse terá sido o entendimento do legislador ao referir, no n. ${ }^{\circ} 19$ do artigo $19 .^{\circ}$ da referida lei, que "os bancos de produtos biológicos constituídos para fins forenses de identificação criminal ou outros devem ser objecto de regulamentação específica".

Entre os diversos diplomas tomados em consideração pela comissão salienta-se a Lei de Protecção de Dados Pessoais ${ }^{18}$. Os conceitos de dados pessoais, ficheiros de dados pessoais, normas relativas ao consentimento e aspectos relacionados com o tratamento e interconexão dos dados foram assimilados da referida lei, procurando-se que o projecto em nada contrariasse as orientações estabelecidas nesse diploma.

Também os pressupostos estabelecidos no Código de Processo Penal foram amplamente considerados, designadamente no que se refere às questões relativas à sujeição a exame e ao despacho que ordena a perícia, entre outros aspectos. Salienta-se que não houve qualquer indicação no sentido da articulação entre os trabalhos da comissão que preparou o projecto relativo à criação da base de dados e da que procedia à revisão do Código de Processo Penal.

A comissão elaborou o projecto durante o ano de 2006, tendo solicitado e tomado em consideração o parecer de múltiplas entidades e personalidades de algum modo ligadas a este tema, através de um inquérito elaborado para esse

18 Lei n. $67 / 98$, de 26 de Outubro. 
efeito, elencando as questões mais problemáticas e controversas.

Foi realizado o levantamento nacional e internacional de estudos, artigos de opinião e resultados das bases de dados genéticos em funcionamento, o que permitiu à comissão a análise comparada das questões suscitadas por esta matéria.

Em 27 de Outubro de 2006, o INML organizou, conjuntamente com o Centro de Direito Biomédico da Universidade de Coimbra, um seminário internacional ${ }^{19} \mathrm{em}$ que foram apresentadas e discutidas, por representantes de diversos países, as principais bases de dados em funcionamento.

A proposta de diploma foi concluída pela comissão, tendo sido entregue ao Ministro da Justiça no dia 18 de Dezembro de 2006.

No início de 2007, o Governo colocou em discussão pública o projecto20.

Foi solicitado parecer à Comissão Nacional de Protecção de Dados que se pronunciou ${ }^{21}$ manifestando preocupação pela possibilidade da obtenção de outro tipo de informação a partir do ADN não codificante, além da necessária para a identificação genética individual. O parecer considerou positiva a criação da base de dados para fins de investigação criminal, defendendo contudo a inadmissibilidade da coercibilidade física para submissão ao exame e a obrigatoriedade da existência de decisão judicial fundamentada. No

19 Decorreu na Faculdade de Direito da Universidade de Coimbra.

20 Apesar de se ter procurado uma participação pública alargada e de o Ministério da Justiça ter colocado o projecto, durante cerca de três meses, na sua página electrónica, com relevo na página de abertura, não houve um único comentário, sugestão ou crítica que tivesse sido apresentado.

21 Através dos seus pareceres n. ${ }^{\circ}$ 18/2007, de 19 de Abril de 2007, e n. ${ }^{\circ}$ 41/2007, de 16 de Julho de 2007. que se refere ao critério temporal da inserção do perfil, considerou excessiva a inserção de perfis de condenados a penas concretas de 3 anos de prisão, referindo dever ser substituída pela pena concreta de 10 ou, no máximo admitido, de 5 anos de prisão efectiva. No que se refere à vertente da identificação civil22 considerou não ser necessária e ser excessiva, "dada a sua obrigatória universalidade, por um lado, e dada a excepcionalidade da finalidade da sua criação", apenas se concebendo "no contexto de catástrofes e acidentes imprevisiveis e absolutamente excepcionais".

O Conselho Nacional de Ética para as Ciências da Vida pronunciou-se ${ }^{23}$ considerando justificável a criação de uma base de dados de perfis de ADN, desde que salvaguardados os princípios de transparência, independência e qualidade. O parecer orientou-se no sentido de a base poder conter perfis de pessoas condenadas por crimes graves ou inimputáveis perigosos, no que se refere à vertente criminal, bem como perfis para identificação de vítimas e de pessoas desaparecidas e seus familiares. Chamou a atenção para a necessidade da eliminação dos dados, no caso de algum dos marcadores vir a demonstrar uma associação a uma doença ou um traço comportamental. Além da obtenção do consentimento informado, escrito e revogável por parte de voluntários, familiares de pessoas desaparecidas e profissionais, defendeu que se deveria obter também o assentimento das pessoas condenadas. Foi defendida a destruição das amostras biológicas identificadas, após a obtenção dos perfis, tendo sido peremptória a recusa

22 Apesar do registo de que o fundamento da sua criação se destinava à identificação de desaparecidos.

23 Através do seu parecer n. 52/CNECV/2007, de 12 de Junho de 2007. 
da possibilidade de recurso, para fins criminais, a bancos de material biológico pré-existentes criados com fins médicos ou de investigação. Foi considerado que tanto a custódia das amostras como da base de dados deveria estar a cargo de uma entidade independente, pluridisciplinar e que não fosse parte interessada na investigação. Quanto a aspectos relativos à segurança dos dados, referiu-se a necessidade de uma separação entre o ficheiro dos dados pessoais e o ficheiro dos perfis de $A D N$, bem como a limitação da cooperação internacional à partilha de perfis de ADN e não de amostras biológicas.

Em 8 de Junho de 2007 a proposta de Lei 144/X deu entrada na Assembleia da República. Foi aprovada na generalidade, no dia 27 de Setembro de $2007^{24}$. A aprovação final global ocorreu no dia 6 de Dezembro de $2007^{25}$.

A lei que aprovou a criação em Portugal da base de dados de perfis de ADN foi finalmente publicada em 12 de Fevereiro de 2008 (Lei n. ${ }^{\circ}$ 5/2008).

No que se refere ao funcionamento da base de dados, alguns pontos foram acrescentados à versão entregue pela comissão que preparou a proposta, entre os quais:

- artigo 8०: acrescentado o n. ${ }^{\circ} 6$;

- artigo 19: a proposta previa, no n. ${ }^{\circ} 1$, que a comunicação dos dados pudesse ser feita "... aos magistrados do processo,

24 Com votos a favor do PS e do PSD, votos contra do PCP, do BE, de Os Verdes e de dois Deputados do PSD e a abstenção do CDS-PP.

25 Com votos a favor do PS e do PSD, votos contra do PCP, do BE, de Os Verdes, de 2 Deputados do PSD e de uma Deputada não inscrita e a abstenção do CDS-PP. aos órgãos de polícia criminal e ao INML", passando a redacção final a permitir a comunicação dos dados "ao juiz competente consoante o tipo ou fase do processo, mediante requerimento fundamentado";

- artigo 26: acrescentados a alínea e) no n. 1 e o n. ${ }^{\circ} 2$;

- artigo 34: o n. ${ }^{\circ} 2$ passou a limitar a utilização como meio probatório das amostras colhidas ao abrigo do disposto no n. ${ }^{\circ}$ 1 do artigo $8 .^{\circ}$ ao respectivo processo.

Nos termos do artigo 39. da Lei n. ${ }^{\circ}$ 5/2008, o regulamento de funcionamento da base de dados seria aprovado pelo conselho médico-legal do INML, no prazo de seis meses após a publicação da lei. O referido regulamento foi elaborado, discutido e aprovado pelo conselho médico-legal na sua reunião de 15 de Julho de $2008^{26}$.

O conselho de fiscalização da base de dados, estabelecido pelo artigo $29 .^{\circ}$ da Lei n. ${ }^{\circ}$ 5/2008, após eleição, foi designado pela Assembleia da República em 26 de Fevereiro de 200927.

Elementos do INML foram aos Estados Unidos da América fazer formação no laboratório do FBI na Virginia28, tendo ficado habilitados a trabalhar com o programa CODIS ${ }^{29}$. O programa CODIS foi instalado no INML em Março de 2009³0, tendo

26 Vindo a ser publicado em Diário da República, 2. ${ }^{a}$ série, n. ${ }^{\circ} 234$, de 3 de Dezembro de 2008.

27 Constituído pelo Conselheiro Manuel Simas Santos,

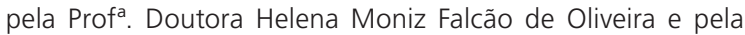
Profa. Doutora Paula Ribeiro de Faria, nos termos da Resolução da Assembleia da República n. ${ }^{\circ}$ 14/2009.

28 Em Fevereiro de 2009.

29 Combined DNA Index System.

30 Instalação concretizada entre 16 e 18 de Março de 2009, pelo Dr. Kenneth Walker, CODIS International Installation 
sido modificado no sentido da sua adaptação à Lei n. ${ }^{\circ}$ 5/2008.

Tal como previsto no artigo $12 .^{\circ}$ da Lei $n .^{\circ}$ 5/2008, a portaria conjunta dos Ministérios da Justiça e da Saúde relativa aos marcadores de ADN a integrar a base de dados foi publicada em 17 de Março de 2009³1.

Na sequência de candidatura a programa da Comissão Europeia ${ }^{32}$, o INML conseguiu obter financiamento que lhe permitiu adaptar os seus laboratórios às exigências periciais acrescidas relacionadas com a criação e entrada em funcionamento da base de dados de perfis de ADN.

De acordo com o estabelecido pelo artigo $16 .^{\circ}$ do regulamento de funcionamento da base de dados de perfis de ADN, foi elaborado um manual de procedimentos relativo às regras técnicas do seu funcionamento, com vista a assegurar a qualidade, a segurança e a confidencialidade da base. O manual de procedimentos foi elaborado por elementos do INML e do LPC ${ }^{33}$.

Face à necessidade de serem observados critérios rígidos relativos à colheita das amostras, tanto a nível dos laboratórios que procedem à realização das análises como pelos restantes serviços médico-legais e por autoridades policiais, foram elaboradas normas específicas de recolha de amostras no âmbito da base de dados de perfis de $A D N^{34}$, por elementos do INML e do LPC,

Coordinator, e pelo Eng ${ }^{\circ}$. César Ferreira, Coordenador Técnico designado pelo INML para a base de dados.

31 Portaria n. ${ }^{\circ}$ 270/2009.

32 "Prevention of and Fight against Crime 2007", da anterior Direcção-Geral da Justiça, Liberdade e Segurança.

33 Aprovado em reunião do Conselho Directivo do INML em 16 de Novembro de 2009.

34 Aprovadas em reunião do Conselho Directivo do INML em 26 de Abril de 2010. tendo sido divulgadas pelas entidades referidas que procedem a colheitas.

O primeiro perfil de ADN foi inserido na base de dados no dia 12 de Fevereiro de 2010, ou seja, dois anos após a publicação da Lei n. ${ }^{\circ}$ 5/2008.

Por Resolução de 7 de Junho de 2013, na sequência de eleição, foi designado pela Assembleia da República o novo Conselho de Fiscalização da base de dados de perfis de $A D N^{35}$.

A Lei n. ${ }^{\circ}$ 40/2013, de 25 de Junho, veio aprovar a organização e funcionamento do conselho de fiscalização da base de dados de perfis de $A D N^{36}$, bem como proceder à primeira alteração deste diploma. Previa a Lei n. ${ }^{\circ}$ /2008, no seu artigo $5 .^{\circ}$, n. ${ }^{\circ}$, que "Sob proposta de uma das entidades referidas no número anterior [LPC ou INML], e com autorização do Ministério da Justiça e do ministério que tutela o laboratório proposto, a análise dos perfis de ADN pode ser realizada por outros laboratórios". A nova redacção do referido n. ${ }^{\circ} 2$ passou a dizer apenas que a "Análise dos perfis de ADN pode ser realizada por outros laboratórios, mediante autorização do Ministério da Justiça e do ministério que exerça tutela sobre eles" 37.

35 Constituído pelo Desembargador António Casebre Latas, pelo Médico e Deputado Dr. Ricardo Baptista Leite e pela Advogada Dra. Maria Helena Terra Brandão de Sousa, nos termos da Resolução da Assembleia da República n. ${ }^{\circ}$ 81/2013.

36 De acordo com o previsto no artigo $30{ }^{\circ}$ da Lei n. ${ }^{\circ}$ $5 / 2008$

37 O enunciado existente justificava-se pelo facto de ter sido entendido que no caso de excesso de determinações judiciais de inserção de perfis, que ultrapassassem as capacidades dos laboratórios do LPC e do INML, estas entidades públicas poderiam solicitar apoio a outros laboratórios que oferecessem garantias de qualidade, o que estariam em condições de comprovar dado ser a área em que exercem actividade. 


\section{CARACTERÍSTICAS}

\section{DA BASE DE DADOS}

\subsection{CRITÉRIOS DE INCLUSÃO}

No que se refere aos critérios de inclusão, várias questões e hipóteses foram equacionadas e amplamente discutidas, entre as quais as seguintes:

a) Criar uma base de dados geral ou inserção dirigida a um determinado grupo?

b) Limitar a base de dados à vertente da investigação criminal ou incluir também a vertente da identificação civil?

c) No âmbito criminal, inserir apenas perfis de condenados ou incluir também perfis de suspeitos ou arguidos?

d) Ter como critério de inserção a medida da pena ou estabelecer um catálogo de crimes?

e) Que medida de pena estabelecer?

3.1.1. Várias foram as propostas no sentido de ser criada uma base de dados geral, que incluísse toda a população Portuguesa. Tal proposta foi apresentada, sobretudo, por juristas, pois as pessoas com formação na área científica defendiam, de forma quase consensual, a existência de uma base de dados mais limitada. O principal argumento jurídico apresentado sustentava-se no fundamento de que estaria mais conforme à Constituição a criação de uma base de dados geral em vez de uma outra que incluísse apenas um determinado grupo da população, embora tal não tivesse sido também consensual entre os juristas consultados. Defendia-se essa posição com a justificação de que uma lei deve ser geral e abstracta, não podendo ser aplicável apenas, no caso, a um predeterminado grupo de pessoas condenadas. Foram apresentadas algumas sugestões sobre como poderia ser construída essa base de dados geral, entre as quais a da possibilidade da recolha sistemática de amostras aos recém-nascidos ou a colheita a todos os cidadãos aquando da renovação do bilhete de identidade. Foi dado o exemplo do projecto da identificação dos cerca de 270000 habitantes da Islândia ${ }^{38}$, apesar de se saber que essa base de dados teve finalidades essencialmente clínicas.

No entanto, vários argumentos relevantes foram apresentados contra tais propostas. Desde logo a inexequibilidade da sua concretização em breve prazo. Portugal não possuía, nem possui, laboratórios com capacidade suficiente para proceder a centenas de milhares de análises anuais e seria extremamente dispendioso e moroso ter de criar novos laboratórios e formar recursos humanos que pudessem dar resposta a essas exigências. Salienta-se que a comunidade científica internacional considera que um perito poderá subscrever autonomamente um relatório pericial apenas após três anos de exercício de actividade pericial. E, além disso, seria uma opção menos segura a de que novos laboratórios e pessoas recentemente contratadas para o efeito assumissem a responsabilidade da determinação de perfis de ADN para inserir numa base de dados, em comparação com laboratórios e peritos com anos de experiência no exercício pericial.

Por outro lado, tal solução apresentaria uma taxa proporcional de sucesso no apoio à

38 DeCode Genetics. 
investigação criminal muito inferior à verificada para a generalidade dos países. Dado que apenas uma determinada proporção de indivíduos de uma população comete crimes, se analisássemos os perfis de ADN de toda a população em vez de somente os que estão envolvidos em actividades criminosas, a taxa proporcional de sucesso seria naturalmente inferior. O número de sucessos seria superior, mas a proporção de resultados positivos relativamente ao total analisado seria seguramente muito inferior. Em resumo, seria uma solução muito mais dispendiosa, com uma taxa proporcional de sucesso inferior, portanto mais difícil de defender, além de ser inexequível a breve prazo em Portugal. Não sendo uma solução rejeitada pela maioria dos que se pronunciaram quanto a este aspecto, entendeu-se que seria mais adequado avançar por etapas: elaborar, em primeiro lugar, uma proposta dirigida aos processos de investigação que pudessem beneficiar das potencialidades de uma base de dados e, futuramente, perspectivar o seu alargamento à população em geral ${ }^{39}$.

Assim, apesar de ter os seus defensores e de constituir uma proposta com argumentos muito válidos, a solução da criação de uma base de dados geral a curto prazo acabou por ser preterida.

3.1.2. No que se refere à questão de limitar a base de dados à vertente da investigação criminal ou incluir também a vertente da identificação civil, foi praticamente consensual a aceitação das potencialidades que a inclusão de perfis de ADN com fins de identificação civil poderia trazer. Não obstante o facto de a maioria dos países europeus

39 Uma solução semelhante às propostas que têm sido feitas no Reino Unido, face à constatação de que a base de dados inclui já a generalidade dos cidadãos criminosos. privilegiar a vertente criminal nas suas bases de dados, alguns incluem também o âmbito da identificação civil. Uma base de dados de perfis de ADN poderá ser útil para a identificação de corpos, não apenas em situações de catástrofes, mas também para apoiar os casos isolados com que se confrontam os serviços médico-legais no decurso da sua actividade pericial diária. Aliás, as bases de dados de âmbito nacional servem essencialmente este último propósito e não o primeiro, ao contrário do que foi defendido pela generalidade dos que justificavam não serem necessárias as finalidades de identificação civil da base de dados, referindo que em Portugal não ocorriam muitas catástrofes. Se ocorrer uma catástrofe no nosso País, quer se trate de uma situação usualmente chamada de catástrofe fechada ${ }^{40}$ (como pode ser a queda de avião) ou de uma catástrofe aberta ${ }^{41}$ (como, por exemplo, um terramoto), existe usualmente uma investigação concertada, sob a coordenação de um magistrado do Ministério Público. Mesmo na ausência de lei própria para uma base de dados perfis de ADN, nada impediria que fosse criada uma base de dados específica para investigação do caso concreto, com o objectivo de comparar os perfis obtidos das vítimas com os dos familiares das pessoas envolvidas ou outras amostras de referência. Tal aconteceu por diversas ocasiões, sempre que necessário e determinado pela autoridade judiciária. Nunca foi aí que residiu o problema, porque a legislação possuía mecanismos de responder a essa necessidade da investigação pericial.

40 Em que é conhecido o número de vítimas.

41 Em que pode não ser conhecido o número e a identidade das vítimas. 
O problema colocava-se no caso dos corpos não identificados que iam dando entrada nos serviços médico-legais e que, após o recurso a todas as outras metodologias de identificação possíveis, eram inumados por identificar. Simultaneamente existiam pedidos de familiares de pessoas desaparecidas e de autoridades policiais no sentido de se saber se determinados corpos teriam dado entrada nalgum dos serviços médico-legais do País. Havendo alguma suspeita de que um determinado corpo pudesse pertencer a uma pessoa específica, mesmo que surgido em local distinto do que seria de esperar ou mesmo que muito tempo após o seu desaparecimento, nada impedia que o magistrado responsável pelo processo mandasse proceder à comparação genética. A maior dificuldade colocava-se quando não havia qualquer suspeita. Nessas circunstâncias sempre foi entendimento do INML (apesar de ser um instituto com abrangência de actuação a todo o território nacional e de ser tecnicamente possível a confrontação entre os diferentes casos isolados) que não lhe era permitido estar a comparar distintos processos, sob a alçada de diferentes (ou até dos mesmos) tribunais, sem uma determinação de um magistrado nesse sentido. Este foi o objectivo principal que justificou a necessidade da vertente de identificação civil da base de dados e não o problema das catástrofes, como erroneamente se interpretou.

Mas acrescenta-se, no que se refere às grandes catástrofes, nomeadamente às catástrofes abertas, que por vezes nem todos os corpos são identificados nem aparecem todas as pessoas desaparecidas. Nessas circunstâncias, o processo de identificação das vítimas poderá prolongar-se por muitos anos sem que o processo seja encerrado.
A questão que aqui se poderia colocar seria a da opção entre uma base de dados para cada uma das catástrofes que pudessem ocorrer ou ter apenas uma única base de dados nacional que integrasse estes diferentes processos. Não temos dúvidas em defender que é vantajosa a existência de apenas uma única base de dados nacional. Existindo mais do que uma grande catástrofe, em que nem todas as vítimas tenham sido localizadas e identificadas, seria possível o aparecimento posterior de corpos cujos perfis teriam de ser comparados com as diversas bases de dados até à sua identificação. Seria um processo complexo e desnecessário face à alternativa da existência de apenas uma única base de dados nacional que permita a comparação entre os perfis de todos os corpos não identificados que apareçam (independentemente do local e do tempo) com todos os perfis de familiares de pessoas desaparecidas ou de outras amostras de referência.

3.1.3. No que diz respeito à vertente criminal da base de dados de perfis de ADN colocou-se a questão de inserir apenas perfis de condenados ou incluir também perfis de suspeitos ou arguidos.

O facto de o processo de criação da base de dados nacional ter sido iniciado quando a maioria dos países europeus possuía já experiência de vários anos de funcionamento das suas bases de dados permitiu ter em consideração os respectivos resultados. Nesse âmbito, constatou-se uma taxa de sucesso superior para suspeitos ${ }^{42} \mathrm{em}$ comparação com condenados, no que se refere a coincidências obtidas. A inclusão de perfis de

42 Tradução de suspects, o que pode incluir o correspondente a suspeitos e a arguidos, dependendo dos ordenamentos jurídicos de cada país. 
suspeitos foi observada em países como o Reino Unido, a Áustria, a Alemanha, a Finlândia ou a Suiça, entre outros. Além disso, foi consensual, entre os investigadores criminais consultados, a opinião de que seria útil a inclusão de perfis de ADN de suspeitos na base de dados nacional.

No entanto, foi também praticamente consensual, entre os juristas que se pronunciaram relativamente a este aspecto, que a previsão de um ficheiro de suspeitos ou arguidos na base de dados levaria a que a proposta pudesse ser inconstitucional, com o argumento de que esses cidadãos são inocentes até prova em contrário.

Neste aspecto, como em diversos outros, a comissão que elaborou a proposta optou pela posição mais cautelosa, sempre no pressuposto de que seria mais benéfico para o País ter uma base de dados mais restritiva mas que pudesse ser aprovada, do que apresentar uma proposta mais arrojada que não conseguisse obter o consenso suficiente para a sua aprovação e que levaria, provavelmente, a mais alguns anos de discussão e de atraso na criação desta importante ferramenta. A experiência observada em diversos outros países mostrou também que muitos começaram com bases de dados restritivas e que, progressivamente e à medida que os receios iniciais foram desaparecendo e a sociedade passou a conhecer melhor e a ter mais confiança neste instrumento, alargaram a sua abrangência. Assumidas voluntariamente, as opções foram no sentido referido, deixando para uma fase posterior os aperfeiçoamentos que a experiência viesse a demonstrar necessários.

No entanto, e para de algum modo se poder satisfazer as necessidades legítimas da investigação criminal, foi prevista a possibilidade de interconexão de perfis de arguidos com os perfis de amostras problema existentes na base de dados. Essa possibilidade pode ser exercida sempre que for entendido necessária, nos termos da lei aprovada. Por essa via não se equipararam os arguidos aos condenados, no sentido da permanência dos seus perfis na base de dados, mas não se retirou à investigação criminal uma ferramenta que lhe pode ser extremamente útil, salvaguardados os direitos daqueles cidadãos.

3.1.4. Quanto à questão de ter como critério de inserção a medida da pena ou um catálogo de crimes, observou-se não serem uniformes as opções seguidas nos diversos estados europeus. Países como a Holanda, a Suécia, a Dinamarca ou a Suíça optaram por ter como critério a medida da pena. França, Finlândia ou Noruega, entre outros, definiram um catálogo de crimes como critério de inclusão.

Esta foi uma das questões em que não houve unanimidade de opiniões, nem no seio da comissão que preparou a proposta legislativa, nem nas pessoas consultadas sobre a matéria. Acabou por prevalecer o critério da medida da pena. Um dos argumentos que mais pesou consistiu na constatação de que a genética forense pode cada vez mais fornecer resultados não apenas nos crimes contra a vida e as pessoas, em que com maior probabilidade pode existir material biológico facilmente identificável, mas também noutro qualquer tipo de crime, em que pode ser possível a identificação de um perfil genético num documento manuseado ou num objecto agarrado. Não haveria, assim, qualquer critério científico sólido que constituísse um argumento irrefutável para escolher alguns crimes em detrimento de outros. Não havendo argumento científico irrefutável, 
com que justificação se escolheriam alguns crimes relativamente a outros? Que outro critério, melhor do que o da gravidade do crime cometido poderia ser considerado? Fixando o Código Penal a mesma medida de pena para dois tipos de crime distintos, com que fundamento se incluiria um deles e se excluiria o outro? Assim, apesar de não ter existido unanimidade no seio da comissão, a opção pelo critério da medida da pena foi a posição maioritária e que acabou por ser apresentada na proposta final.

3.1.5. A questão que se colocou em seguida foi a de qual a medida da pena a considerar. Não havia um padrão uniforme entre os diversos países que tinham optado pelo critério da medida da pena: a Suíça estabeleceu como critério um ano, a Dinamarca um ano e meio, a Suécia dois anos, a Holanda quatro anos, etc. Através dos resultados observados em vários países, concluiu-se que não apenas crimes muito graves ou graves obtinham coincidências identificativas nas diversas bases de dados, mas também crimes de menor gravidade. Por exemplo as situações em que tinha ocorrido o crime de roubo caracterizavam-se por uma taxa de identificação muito elevada dos seus supostos autores. Além disso, foram tomados em consideração dados que apontavam para a utilidade da inserção precoce do perfil de ADN de um indivíduo que se inicie em actividades criminosas. Investigadores criminais consultados referiram não apenas a observação de uma tendência repetitiva no cometimento de alguns tipos de crime, mas principalmente a circunstância de que é comum o início das actividades criminosas com crimes de pequena gravidade, com evolução posterior para crimes de maior gravidade. A título de exemplo, dados da Grã-Bretanha tomados em consideração afirmavam que menos de um quarto das detenções se referiam a novos indivíduos, 85\% dos criminosos tinham a sua primeira condenação entre os 14 e os 19 anos de idade, a probabilidade de um indivíduo de 14 anos reincidir no crime era de $77 \%$ e que $20 \%$ dos criminosos cometiam $80 \%$ dos crimes ${ }^{43}$.

Contudo, um dos aspectos a observar teria necessariamente de ser a exequibilidade da proposta legislativa. Foi entendido que não deveria ser apresentada uma proposta que não fosse possível de concretizar com os meios laboratoriais ao dispor do País ou, pelo menos, que não implicasse investimentos muito avultados para as capacidades financeiras nacionais.

Com base nos dados estatísticos disponibilizados pelo Ministério da Justiça, foi feito um levantamento sobre o número de condenações existentes de acordo com a medida da pena aplicada. Verificou-se, no que diz respeito a condenações com pena igual ou superior a três anos, que havia cerca de seis mil condenações por ano em Portugal. Admitindo-se que, no limite, todas as condenações implicassem a determinação do perfil genético, tal acréscimo de exames laboratoriais seria possível de suportar pelos quatro laboratórios perspectivados para a realização das perícias (os três laboratórios do INML e o LPC), com o eventual apoio de outro laboratório nacional cumpridor dos requisitos de qualidade, se se viesse a revelar necessário.

43 BUSHER, L. - The use of the UK National DNA Database to support an intelligence-led approach to the investigation of crime. Journal de Médecine Légale Droit Médical. (2002), p. 21-25. 
Apesar de ter sido defendida uma maior abrangência da base de dados, por exemplo estabelecendo como critério de inserção uma condenação com uma pena igual ou superior a dois anos ou até igual ou superior a um ano (à semelhança de outros países), tal facto originaria a necessidade de realizar dezenas ou centenas de milhares de exames laboratoriais o que seria absolutamente impossível de concretizar a breve prazo com os recursos actualmente existentes. E se fosse necessário criar novos laboratórios e formar muito mais pessoas, o nosso País iria ter de aguardar alguns anos até que fosse possível ter todas essas condições, além do investimento avultado que teria de ser feito. Mais uma vez se introduziria um risco acrescido para a segurança dos resultados se fosse atribuída a responsabilidade da determinação de perfis de ADN para inserção numa base de dados a pessoas recentemente contratadas ou a laboratórios sem experiência consolidada de exames de genética forense.

A perspectiva da determinação do perfil de ADN na generalidade dos casos em que ocorresse uma condenação com pena concreta de prisão igual ou superior a três anos teve como pressuposto a automaticidade da inserção, desde que verificados os requisitos legais confirmados por magistrado judicial ${ }^{44}$.

Face ao enunciado da Lei, a defesa da automaticidade da inserção, no caso da condenação em pena concreta de prisão igual ou superior a três anos, é apontada por Inês Ferreira Leite ${ }^{45}$ e

44 O que não se veio a verificar, pelo número de perfis inseridos após quatro anos de funcionamento da base de dados.

45 A nova base de dados de perfis de $A D N »$, Boletim Informativo da FDUL-IDPCC, Ano 1, Ed. 5, Outubro-Novembro 2009 (nota 16).
Paulo P. Albuquerque ${ }^{46}$, sendo defendida uma "quase automaticidade" por Jorge Reis Bravo ${ }^{47}$. A jurisprudência divide-se entre a propensão para a automaticidade ${ }^{48}$ e o entendimento contrário ${ }^{49}$.

Em suma, a proposta contemplou a possibilidade de inserção de perfis para investigação criminal (amostras problema e condenados), perfis para identificação civil (amostras problema e amostras referência), perfis de voluntários (com as duas finalidades) e perfis de profissionais (para detecção de contaminações).

A Lei n. ${ }^{\circ}$ 5/2008 veio estabelecer a criação dos seguintes ficheiros, de acordo com as respectivas alíneas do seu artigo $15^{\circ}$ :
a) ficheiro de voluntários;
b) ficheiro de amostras problema para iden- tificação civil;
c) ficheiro de amostras referência para iden- tificação civil;

46 Comentário do Código de Processo Penal à luz da Constituição da República e da Convenção Europeia dos Direitos do Homem, 3. . . ed. actualiz. Universidade Católica Ed., Lisboa, 2009, p. 467.

47 Perfis de ADN de arguidos-condenados (o art. 8. ${ }^{\circ}$, n. ${ }^{\text {os }}$ 2 e 3, da Lei n. ${ }^{\circ}$ 5/2008, de 12-02, Revista Portuguesa de Ciência Criminal - Ano 20, N. ${ }^{\circ}$ 1, 2010 e I. O aprofundamento da cooperação transnacional em matéria de intercâmbio de prova genética. II. A ordem de recolha de amostras em condenados, para análise e inserção na Base de Dados de Perfis de ADN. Abordagens preliminares. Encontro de trabalho. Conselho de Fiscalização da Base de Dados de Perfis de ADN -Procuradora- Geral da República e P. G. Distritais. Aspetos Práticos e Teóricos do Funcionamento da Base de Dados de ADN e da Obtenção da Prova por ADN em Processo Penal. Coimbra, 07 de março de 2014.

48 Acórdãos da Relação de Évora de 13.12.2011 (relator Desembargador Alberto João Borges) e de 15.05.2012 (relator Desembargador António J. Latas).

49 Acórdão da Relação de Lisboa de 11.10.2011 (relator Desembargador Agostinho Torres). 
d) ficheiro de amostras problema para investigação criminal;

e) ficheiro de condenados;

f) ficheiro de profissionais.

No seu artigo $18 .^{\circ}$, a Lei n. ${ }^{\circ}$ 5/2008 definiu quem possui legitimidade para mandar inserir os perfis de ADN:

- os perfis relativos a voluntários, a parentes de pessoas desaparecidas ou a profissionais são inseridos mediante o seu consentimento livre, informado e escrito ${ }^{50}$;

- os perfis relativos a amostras problema para investigação criminal ou para identificação civil são inseridos mediante despacho do magistrado competente no respectivo processo ${ }^{51}$;

- os perfis relativos a condenados são inseridos mediante despacho do juiz de julgamento ${ }^{52}$.

\subsection{CRITÉRIOS DE INTERCONEXÃO}

A interconexão de perfis deve estar sujeita a regras estritas, no sentido de garantir que apenas é possível a sua utilização para os fins que motivaram a respectiva colheita. Cada nova inserção origina a realização das interconexões previstas na lei, sem necessidade de qualquer determinação suplementar. A lei estabelece a necessidade de um despacho de magistrado para a inserção de um perfil de uma amostra problema

50 Alíneas a) e b) do $n^{\circ} 1$ do artigo $18^{\circ}$.

$51 \mathrm{~N}^{\circ} 2$, do artigo $18^{\circ}$.

$52 \mathrm{~N}^{\circ} 3$, do artigo $18^{\circ}$ ou de um condenado nos respectivos ficheiros da base, não exigindo um despacho autónomo para a interconexão. Assim, cada inserção origina as interconexões previstas na lei, que são realizadas pelo programa informático que foi adaptado à Lei n. ${ }^{\circ}$ 5/2008, de 12 de Fevereiro.

Os perfis de parentes de pessoas desaparecidas bem como de outras amostras referência de pessoas desaparecidas apenas são cruzados com os perfis relativos às amostras problema para identificação civil ${ }^{53}$.

Os perfis dos voluntários são cruzados com todos os ficheiros da base de dados ${ }^{54}$.

Os perfis de amostras problema para investigação criminal e os perfis de condenados são cruzados com todos os ficheiros, excepto com os perfis relativos às amostras referência para identificação civil ${ }^{55}$.

No que se refere aos perfis dos arguidos ${ }^{56}$, apesar de não poderem ser inseridos na base de dados de perfis de ADN, pois não existe ficheiro de arguidos, poderão ser comparados com os perfis das amostras problema para investigação criminal e amostras problema para identificação civil, além de com os perfis dos profissionais ${ }^{57}$.

$\mathrm{O}$ facto de ter sido proposto que o artigo $8^{\circ}$ n. ${ }^{\circ}$, da Lei n. ${ }^{0}$ 5/2008, se limitasse à possibilidade de interconexão de perfis de indivíduos com o estatuto processual de arguido e excluísse que tal pudesse ser concretizado no caso de meros suspeitos deveu-se à circunstância de se saber que

53 Artigo $20^{\circ}, n^{\circ} 2$, da Lei $n .^{\circ}$ 5/2008, de 12 de Fevereiro.

54 Artigo $20^{\circ}, n^{\circ} 3$, da Lei n. ${ }^{\circ}$ 5/2008, de 12 de Fevereiro.

55 Artigo $20^{\circ}, n^{\circ} 4$, da Lei $n .^{\circ}$ 5/2008, de 12 de Fevereiro.

56 Amostras colhidas ao abrigo do artigo $8^{\circ}, n^{\circ} 1$, da Lei n. ${ }^{\circ}$ /2008, de 12 de Fevereiro.

57 Artigo $20^{\circ}, n^{\circ} 1$, da Lei n. ${ }^{\circ}$ 5/2008, de 12 de Fevereiro. 
à medida que a base de dados vai aumentando em número de perfis maior a possibilidade de ocorrer uma coincidência fortuita entre o perfil de uma amostra referência e um perfil de uma amostra problema que não estando relacionada com um crime foi colhida no respectivo exame do local. É sabido que nem todas as amostras colhidas em locais de crime estão relacionadas com esse crime. Pessoas que de forma fortuita tenham estado presentes nesse local, antes ou após a ocorrência de um crime, poderão deixar involuntariamente uma amostra biológica que não está relacionada com o crime. Assim, para evitar essas "falsas" coincidências, elevou-se o grau de exigência para a possibilidade de interconexão de perfis de indivíduos em processo de investigação criminal, exigindo-se o estatuto de arguido. Este estatuto tem como pressuposto a existência prévia de fundadas suspeitas no envolvimento em determinado crime e, além disso, confere garantias processuais e constitucionais que o mero suspeito não possui. A opção assumida pretendeu deixar ao critério do magistrado judicial a verificação da necessidade da realização da recolha, tendo em conta o direito à integridade pessoal e à reserva da intimidade do arguido.

Existindo uma coincidência, os respectivos magistrados que determinaram a inserção são informados desse facto, consoante os casos, e, se assim for determinado, a comunicação dos dados será feita aos juízes titulares dos processos.

Em processos individuais, sempre que necessário e nos termos do Código de Processo de Penal, poderão ser realizadas comparações entre suspeito(s) e amostra(s) recolhida(s) em local de crime, como sucedia antes da entrada em vigor da Lei n. ${ }^{\circ}$ 5/2008 e continua a suceder após a sua entrada em vigor. Salienta-se que nunca foi perspectivado ou discutido, pela comissão que preparou o projecto, a aplicação deste diploma às perícias em geral, na área da criminalística biológica. A comissão sempre teve o entendimento de que a proposta que estava a elaborar se aplicaria apenas à base de dados de perfis de ADN, pois apenas para tal estava mandatada, aliás como veio a ficar explícito na designação da Lei n. ${ }^{\circ}$ 5/2008, de 12 de Fevereiro, que "Aprova a criação de uma base de dados de perfis de ADN para fins de identificação civil e criminal".

\subsection{CRITÉRIOS DE REMOÇÃO}

Antes de ser discutido este assunto, a comissão que elaborou a proposta legislativa fez também um levantamento da realidade europeia, no que diz respeito aos critérios de remoção dos perfis de ADN das bases de dados. Se no que se refere aos perfis das amostras problema não foram observadas grandes questões que originassem discordâncias, seguindo-se um critério utilitarista, com os perfis a permanecerem na base de dados enquanto forem necessários, o mesmo não foi observado relativamente aos perfis dos condenados e dos suspeitos/arguidos. Quanto a estes últimos, não foram observados critérios de remoção uniformes nos diversos países europeus.

Constatou-se, por exemplo, que a Alemanha remove os perfis dos adultos após 10 anos de inserção e dos adolescentes após 5 anos. A extensão desse período é possível se houver um perigo de repetição da ofensa, podendo não haver remoção no caso de homicídio ou de crimes sexuais.

Na Suíça os perfis são removidos após 30 anos, podendo também ser removidos após a 
morte. Podem ainda ser removidos mais cedo, aos 20 anos, em determinadas circunstâncias favorecedoras.

Em França, os perfis dos condenados são removidos após 40 anos desde a última sentença ou quando os indivíduos atingem os 80 anos de idade.

No caso da Suécia, os perfis são removidos 10 anos após a sentença cumprida.

Na Bélgica removem-se os perfis 10 anos após a morte do condenado.

No Reino Unido é permitida a retenção dos perfis de forma intemporal. Inicialmente, apenas os perfis das pessoas não condenadas eram removidos, após o que se determinou a não remoção mesmo das pessoas não condenadas. Tal facto motivou a apresentação de duas queixas ${ }^{58}$ no Tribunal Europeu dos Direitos Humanos, que concluiu ter esse procedimento sido violador do artigo 8 da Convenção para a Protecção dos Direitos do Homem e das Liberdades Fundamentais.

Observa-se, assim, uma grande disparidade de critérios de remoção de perfis, não parecendo existir qualquer fundamento uniforme, sob o ponto de vista da investigação criminal, que tenha orientado as decisões dos diversos países.

Não existindo tal critério fundamentado em argumentos relacionados com a investigação criminal, a comissão que preparou o projecto de legislação sentiu a necessidade de propor o que entendeu melhor se adequar à realidade Portuguesa. Tal como havia sido anteriormente defendido por Helena Moniz ${ }^{59}$, a comissão aprovou a proposta

58 S. and Marper v. The United Kingdom: 30562/04 e 30566/04

59 Os problemas jurídico-penais da criação de uma base de dados genéticos para fins criminais, Revista Portuguesa de Ciência Criminal, 12, 2002. de fixação dos mesmos prazos previstos para o cancelamento definitivo do registo criminal, como critério para a remoção dos perfis ${ }^{60}$. Tal proposta foi consonante com as finalidades que presidiram aos princípios em vigor desde o século XIX que visavam conceder ao condenado que cumpriu a sua pena a possibilidade de se ressocializar e reintegrar a sociedade na plenitude dos seus direitos, sem qualquer estigmatização pelo facto criminoso anteriormente cometido. Não tendo sido levado ao conhecimento da comissão qualquer fundamento que justificasse o estabelecimento de prazos mais alargados, a proposta apresentada suportou-se numa normativa existente que, não tendo exactamente os mesmos pressupostos, encontrava analogia com os objectivos pretendidos.

Quanto aos perfis das amostras problema para investigação criminal foi definido que a sua remoção ocorrerá no termo do processo-crime ou no prazo máximo de prescrição do procedimento criminal, quando identificados com o arguido, ou 20 anos após a recolha, quando não identificados com o arguido.

No que se refere à identificação civil, o critério estabelecido foi o da permanência dos perfis na base de dados até que ocorra a identificação, pois a partir dessa data não se justificará a sua

60 A Lei da Identificação Criminal (Lei n. ${ }^{\circ}$ 57/98, de 18 de Agosto), estabelece no seu artigo $15 .^{\circ}$, n. ${ }^{\circ} 1$, alínea a) o seguinte:

Cancelamento definitivo

1 - São canceladas automaticamente, e de forma irrevogável, no registo criminal:

a) As decisões que tenham aplicado pena de prisão ou medida de segurança, decorridos 5, 7 ou 10 anos sobre a extinção da pena ou medida de segurança, se a sua duração tiver sido inferior a 5 anos, entre 5 e 8 anos ou superior a 8 anos, respectivamente, e desde que, entretanto, não tenha ocorrido nova condenação por crime; 
manutenção. Quanto aos perfis relativos aos familiares de pessoas desaparecidas, apesar de o princípio ser o mesmo, a inserção e a permanência na base de dados dependem do consentimento livre, informado e escrito, pelo que o perfil se mantém até à identificação, desde que não haja revogação desse consentimento.

Quanto aos perfis dos voluntários, apenas serão removidos se for revogado o consentimento, prestado de forma livre, informada e escrita, aquando da sua inserção.

Em resumo, nos termos do artigo $26^{\circ}$ da Lei $n .{ }^{\circ}$ 5/2008, a conservação de perfis ocorre da seguinte forma:

a) perfis de voluntários: tempo ilimitado, excepto havendo revogação do consentimento;

b) perfis de amostras problema para identificação civil: tempo ilimitado, até à identificação;

c) perfis de amostras referência para identificação civil: tempo ilimitado, até à identificação, excepto havendo revogação do consentimento no que se refere aos perfis de parentes de pessoas desaparecidas;

d) perfis de amostras problema para investigação criminal:

- se a amostra for identificada com o arguido: no termo do processo crime ou no fim do prazo máximo de prescrição do procedimento criminal;

- se a amostra não for identificada com o arguido: 20 anos após a recolha;

e) perfis de condenados: na data em que se proceda ao cancelamento definitivo no registo criminal;
f) perfis de profissionais: 20 anos após a cessação das funções.

\subsection{CUSTÓDIA DA BASE DE DADOS}

A questão da custódia das bases de dados é frequentemente um dos factores que atrasa a concretização desta importante ferramenta, ao motivar conflitos entre instituições que ambicionam ficar responsáveis pelo seu funcionamento. Tal sucedeu em diversos países, especialmente naqueles em que mais do que uma entidade oficial possuía atribuições para a realização de exames de genética forense. Nalguns a custódia da base de dados ficou sob a alçada de um órgão de polícia e noutros de um instituto de medicina legal ou instituto forense ${ }^{61}$, embora nalguns casos e por motivos diversos se tenham observado algumas alterações posteriores.

Um dos pressupostos internacionalmente reconhecidos para a aceitação de perícias de genética com fins forenses consiste na garantia de que a defesa possui os mesmos direitos na utilização deste meio de prova, seja através de uma decisão judicial ou através de um perito independente. Este constitui um dos pontos fundamentais da Recomendação do Conselho Europeu N. ${ }^{\circ}$ R(92)1, de 10/02/1992, relativa à utilização dos exames de ADN no sistema de justiça criminal.

Esta questão é de extrema relevância para alguns países, como no caso da Alemanha, que

61 Alemanha: Federal Criminal Agency; Áustria: Institute of Legal Medicine; Bélgica: Institut National de Criminalistic; Dinamarca: University Institute of Forensic Genetics; Finlândia: National Bureau of Investigation; Holanda: Netherlands Forensic Institute; Noruega: Institute of Legal Medicine e National Police; Suécia: National Institute of Forensic Science; Suiça: Institut de Médecine Légale. 
chegou a estabelecer no seu Código de Processo Penal ${ }^{62}$ que o exame deve ser ordenado por um juiz, a realização de exames deve ser feita por peritos que não pertençam à entidade que está a prosseguir as investigações e os peritos devem ser independentes, quer sob o ponto de vista da organização, quer sob o ponto de vista da área de trabalho.

No caso Português, o programa do XVII Governo veio determinar que a custódia da base de dados não competiria a órgão de polícia criminal63.

\subsection{NORMAS PROTECTORAS}

Muitas são as normas protectoras estabelecidas na Lei n. ${ }^{\circ}$ 5/2008, de 12 de Fevereiro, que resultaram não apenas das propostas elaboradas pela comissão que preparou o projecto, como das alterações posteriormente introduzidas.

Desde logo o artigo 1.० estabelece que a base de dados foi criada para fins de identificação, sendo expressamente proibida a utilização, análise e tratamento de qualquer tipo de informação obtida das amostras para fins diferentes dos da investigação criminal e da identificação civil.

No que diz respeito às amostras biológicas, apenas os laboratórios que cumpram os requisitos científicos, técnicos e organizacionais internacionalmente estabelecidos ${ }^{64}$ poderão realizar

62 Parágrafo 81 a. $^{\circ}$ e seguintes.

63 Salienta-se que a questão relativa à custódia da base de dados nacional, após ter sido tomada a decisão de a atribuir ao INML, não motivou obstáculos ao excelente entendimento que tem existido entre as duas entidades que, nos termos da lei, ficaram responsáveis pela realização das perícias para a obtenção dos perfis a inserir.

64 Nos termos da Decisão-Quadro 2009/905/JAl do Conselho da União Europeia, de 30 de Novembro de 2009, relativa as análises laboratoriais (artigo 5.'). O artigo 10. obriga a que a recolha das amostras seja realizada através de método não invasivo, como o raspado da mucosa bucal, respeitando a dignidade humana e a integridade física e moral individual. Excepto em situações em que tal seja impossível, deve ser preservada uma parte bastante e suficiente da amostra problema para permitir a realização de uma contra-análise, se necessária (artigo $11 .^{\circ}$ ), repetindo-se os procedimentos técnicos para confirmação de resultados (artigo 13. ${ }^{\circ}$ ). As amostras identificadas referentes aos condenados e aos voluntários são imediatamente destruídas após a obtenção do perfil de ADN, nos termos do artigo $34 .^{\circ}$ da lei. Apesar de ser permitida a cooperação internacional ${ }^{65}$, é proibida a transferência de material biológico para outros países (artigo 21. ${ }^{\circ}$ ).

A inserção dos perfis de ADN na base de dados é feita após a existência de um despacho do magistrado competente no respectivo processo, no caso das amostras problema, ou do juiz de julgamento, no caso dos condenados (artigo 18. ${ }^{\circ}$ ).

No que se refere ao armazenamento dos dados, tem de existir uma separação lógica e física entre o ficheiro dos perfis de ADN e o ficheiro dos dados pessoais, não podendo haver qualquer elemento identificativo do titular dos dados no ficheiro dos perfis de ADN. Os diferentes ficheiros terão de

à acreditação de prestadores de serviços forenses que desenvolvem actividades laboratoriais, os estados membros deverão garantir a respectiva acreditação por um organismo de acreditação nacional que certifique a conformidade dessas actividades com a EN ISO/IEC 17025, até 30 de Novembro de 2013.

65 Designadamente no âmbito da Decisão 2008/615/JAI do Conselho da União Europeia, de 23 de Junho de 2008, relativa à partilha de perfis de ADN com finalidades de apoio à investigação. 
ser manipulados por utilizadores distintos, mediante acessos restritos, codificados e identificativos dos utilizadores (artigo 15..$^{\circ}$ ). Os dados pessoais apenas são comunicados ao juiz competente, mediante requerimento fundamentado, nos termos do artigo 19. ${ }^{\circ}$ da lei. É proibido o acesso de outras pessoas à base de dados, além das previstas na lei (artigo $22 .^{\circ}$ ) e qualquer pessoa tem direito a conhecer o conteúdo dos registos que lhe respeitem (artigo $\left.24 .^{\circ}\right)$, bem como de exigir a correcção de eventuais inexactidões (artigo 25..$^{\circ}$ ).

Todos os procedimentos relativos ao funcionamento da base de dados de perfis de ADN são controlados pelo Conselho de Fiscalização, que responde apenas perante a Assembleia da República, por quem é designado, e pela Comissão Nacional de Protecção de Dados (artigos 29. ${ }^{\circ}, 30 .^{\circ}$ e $37 .^{\circ}$ ). A violação do dever de segredo ou das normas relativas a dados pessoais é punida nos termos da Lei de Protecção de Dados Pessoais e do Código Penal (artigos $35^{\circ}$ e $36 .^{\circ}$ ).

Por último, realça-se a livre valorização da prova por parte dos magistrados, referindo-se que não é permitida uma decisão automatizada que produza efeitos na esfera jurídica de uma pessoa, tomada exclusivamente pelos resultados da base de dados de perfis de ADN (artigo 38..$^{\circ}$ ).

Tais normas, por alguns consideradas excessivas e obstaculizadoras de uma maior eficácia da base de dados, permitiram que os mais receosos e críticos sobre os eventuais riscos que poderiam advir da criação da base de dados pudessem aceitar a versão final do diploma. Recorde-se que, apesar de todas as normas protectoras propostas, o projecto teve votos contra na Assembleia da República, designadamente face aos riscos relativos à salvaguarda dos direitos, liberdades e garantias dos cidadãos.

Entre todas as normas referidas a que mais contestação tem merecido, designadamente pelas autoridades policiais, tem sido a necessidade de obtenção de despacho de magistrado para a inserção de um perfil de uma amostra problema na base de dados. Tal exigência tem sido apontada como a causa do reduzido número de perfis inseridos na base.

\subsection{MARCADORES DE ADN}

Com o objectivo de salvaguardar e limitar o tipo de informação genética a colocar na base de dados, a comissão que preparou o projecto legislativo entendeu que os marcadores de ADN a analisar no âmbito da base de dados não deveriam ser de livre opção dos laboratórios que procedessem à análise laboratorial das amostras nem da entidade que viesse a assumir a custódia da base de dados, propondo, por isso, que fossem definidos sob a forma de portaria governamental. Assim, o artigo 12. ${ }^{\circ}$ da Lei n. ${ }^{\circ}$ 5/2008, de 12 de Fevereiro, veio referir, no seu número 2, que "os marcadores a integrar no ficheiro de perfis de ADN são fixados, após parecer da Comissão Nacional da Protecção de Dados, por portaria conjunta dos membros do Governo responsáveis pelas áreas da justiça e da saúde, de acordo com as normas internacionais e o conhecimento científico sobre a matéria".

Um aspecto fundamental a ter em consideração e que motiva sempre muitas preocupações quando se aborda a temática das bases de dados de perfis de ADN prende-se com a questão da potencial possibilidade de serem obtidas informações de natureza clínica dos dados genéticos presentes nas bases de dados com fins forenses. Esse aspecto 
foi abordado na Resolução do Conselho da Europa de 9 de Junho de 1997, relativa ao estabelecimento de bases de dados de ADN ${ }^{66}$, estabelecendo-se que a possibilidade de partilha de perfis deveria limitar-se à parte não codificante da molécula de ADN, não contendo, por isso, informação sobre características hereditárias específicas de uma pessoa. Também a Resolução do Conselho da Europa de 25 de Junho de 2001, relativa à partilha dos resultados das análises de $A D N^{67}$, veio reforçar este aspecto ao referir que os estados membros deveriam limitar os resultados da análise do ADN às regiões cromossómicas sem expressão genética, acrescentando que se algum dos marcadores aconselhados vier a revelar informação sobre características hereditárias específicas, os estados membros deverão deixar de o analisar. Estabeleceu um conjunto de sete marcadores, designados no seu conjunto por European Standard Set ${ }^{68}$, a ser analisados pelos diversos estados membros, de modo a que fosse possível a partilha de informações.

Na preparação do projecto que deu origem à Lei n. ${ }^{\circ}$ 5/2008 foram assumidos os pressupostos referidos nas resoluções do Conselho de 9 de Junho de 1997 e de 25 de Junho de 2001, no que se refere aos marcadores de ADN a utilizar. Nas definições estabelecidas na Lei n. ${ }^{\circ}$ 5/200869 foi limitada a utilização dos marcadores de $A D N$ àqueles que, segundo os conhecimentos

66 Resolução 97/C 193/02, publicada no Jornal Oficial das Comunidades Europeias: N. ${ }^{\circ}$ C 193, de 24/06/1997, pp. 0002-0003.

67 Resolução 2001/C 187/01, publicada no Jornal Oficial das Comunidades Europeias: N. ${ }^{\circ}$ C 187, 03/07/2001, pp. 0001-0004.

68 VWA, TH01, D21S11, FGA, D8S1179, D3S1358 e D18S51, além da amelogenina.

69 No seu artigo 2.․ alínea e). científicos existentes, não permitem a obtenção de informação de saúde ou de características hereditárias específicas, a que também se chamou, abreviadamente e para maior facilidade de compreensão, "ADN não codificante".

O Regulamento de funcionamento da base de dados concretizou de forma mais clara o que havia sido estabelecido na lei referindo, no seu artigo $11 .^{\circ}$, que "no caso de algum dos marcadores de $A D N$ revelar informação relativa à saúde ou a características hereditárias específicas, esse marcador é excluído dos perfis de ADN incluídos na Base de Dados e deixa de ser estudado nas amostras a analisar posteriormente".

Várias poderiam ser as opções relativas aos polimorfismos de ADN a analisar no âmbito da base de dados. No entanto, deveriam ser tomados em consideração os marcadores definidos na Resolução do Conselho da Europa de 25 de Junho de 2001, pois era importante assegurar a possibilidade de comparação com os perfis inseridos noutras bases de dados europeias.

Mas uma questão mantinha-se ainda por esclarecer: qual o número mínimo de marcadores, com resultados positivos, a estabelecer como critério para a inserção de um perfil na base de dados? Não poderia ser um número muito reduzido, pois correr-se-ia o risco de haver demasiadas falsas coincidências entre perfis, quando fossem feitas comparações. Não poderia ser um número muito elevado, pois tal levaria a que não pudessem ser inseridos muitos perfis, cuja inserção na base de dados seria útil, pelo facto de não ter sido possível a obtenção de resultados positivos em, por exemplo, apenas um ou dois dos polimorfismos obrigatórios. Além disso, se fosse tornado obrigatório um marcador que apenas estivesse contido 
num dos sistemas multiplex usualmente utilizados nos laboratórios forenses, Portugal ficaria dependente das condições contratuais impostas pela respectiva empresa produtora do sistema, sempre que necessitasse de fazer aquisições.

Após análise das opções seguidas noutros países, bem como de alguns casos em que ocorreram $\operatorname{erros}^{70} \mathrm{e}$, principalmente, da capacidade discriminativa resultante da análise de diversos conjuntos de marcadores, tendo em consideração não apenas a dimensão populacional Portuguesa mas também as populações dos restantes países europeus com as quais se iriam realizar comparações ao abrigo da Decisão 2008/615/JAl do Conselho da União Europeia, foi proposta ao Governo a opção da obrigatoriedade de obtenção de resultados positivos nos sete marcadores do European Standard Set como pressuposto para a inserção de um perfil de ADN na base de dados. Este conjunto de marcadores fazia parte dos diferentes sistemas multiplex usualmente utilizados pelo INML e pelo LPC, O que permitiria a inserção de perfis anteriormente determinados por ambas as instituições e a manutenção dos sistemas em uso.

Por outro lado, considerando o facto de haver distintos sistemas multiplex que permitem a obtenção de resultados noutros marcadores, considerando o facto de existirem muitas amostras anteriormente analisadas em que estavam determinados os resultados noutros polimorfismos e considerando o facto de nem todos os países europeus analisarem os mesmos marcadores, foi proposta a possibilidade da inserção dos resultados dos restantes marcadores aceites pela INTERPOL e que incluíam os

70 Como o conhecido UK DNA mismatch ocorrido quando a base de dados inglesa incluía perfis com apenas seis polimorfismos estudados. polimorfismos contidos nos sistemas multiplex mais comumente utilizados pela comunidade científica internacional. A possibilidade de inserção dos resultados destes marcadores, ainda que não sendo de inserção obrigatória, permitiria elevar o poder de discriminação e uma maior segurança nos resultados comparativos com outras bases de dados europeias, evitando situações de falsas coincidências.

Assim, a Portaria n. ${ }^{\circ}$ 270/2009, de 17 de Março, dos Ministérios da Justiça e da Saúde, fixou os seguintes marcadores de ADN a integrar no ficheiro de perfis da base de dados:

a) De inserção obrigatória:

vWA

TH01

D21S11

FGA

D8S1179

D3S1358

D18S51

Amelogenina

b) De inserção complementar:

TPOX

CSF1P0

D13S317

D7S820

D5S818

D16S539

D2S1338

D19S433

Penta D

Penta E

FES

F13A1

F13B

SE33 


\section{CD4}

GABA.

A Resolução do Conselho Europeu de 30 de Novembro de 2009, relativa à partilha de resultados analíticos de $A D N^{71}$, veio alargar a 12 o número de marcadores incluídos no European Standard Set, acrescentando os polimorfismos D1S1656, D2S441, D10S1248, D12S391 e D22S1045. Foi proposta a publicação de nova Portaria que inclua também os referidos polimorfismos, na qualidade de marcadores de inserção complementar.

\subsection{MODO DE FUNCIONAMENTO}

O regulamento de funcionamento da base de dados de perfis de ADN estabeleceu, no seu artigo $16 .^{\circ}$, que o INML deveria criar "um manual de procedimentos relativo a regras técnicas do seu funcionamento, com vista a assegurar a qualidade, a segurança e a confidencialidade da Base". O manual de procedimentos foi elaborado por uma comissão composta por elementos do INML e do LPC, estabelecendo as regras processuais relativas à recolha das amostras, ao envio dos perfis de ADN e dos dados pessoais para a sede do INML, bem como aos procedimentos a realizar com estas informações.

A colheita das amostras para os fins previstos na Lei $n{ }^{\circ}$ 5/2008 obriga a procedimentos específicos que têm de ser tomados em consideração pelas entidades responsáveis, encontrando-se claramente definido quem possui legitimidade para requerer a colheita das amostras. No caso dos voluntários e dos parentes de pessoas desaparecidas, a colheita depende do respectivo consentimento

71 Resolução 2009/C 296/01. livre, informado e escrito. A recolha de amostras problema, quer suponha fins de identificação civil ou de investigação criminal, segue os termos da legislação aplicável, embora para a inserção do perfil na base de dados dependa do despacho do magistrado competente no respectivo processo. A recolha de amostras em arguidos ou condenados é realizada por despacho do juiz, podendo aqueles também apresentar o pedido da colheita.

Nos termos da Lei n. ${ }^{\circ}$ 5/2008 é necessário um despacho do magistrado judicial para a recolha da amostra em condenado ${ }^{72}$ e um outro despacho para a inserção do perfil de ADN na base de dados $^{73}$.

Independentemente da entidade que procede às recolhas, as amostras e os requerimentos ou despachos para a colheita e inserção dos perfis de ADN na base de dados deverão ser encaminhados para uma das entidades competentes para a realização das análises, ou seja, o LPC e o INML. Nos termos de acordo estabelecido entre as duas instituições, os pedidos de colheita de amostra referência recebidos pelo INML serão preferencialmente reencaminhados para o LPC, que procederá à colheita e envio para a delegação do INML da respectiva área de actuação. As perícias relativas a voluntários, familiares de pessoas desaparecidas e condenados sem processo de investigação prévia no LPC são realizadas, preferencialmente, pelo INML.

Previamente à realização da recolha de amostra referência o examinado recebe a informação escrita prevista no artigo 9. ${ }^{\circ}$ da Lei n. ${ }^{\circ}$ 5/2008 ${ }^{74}$.

72 Ao abrigo do disposto no artigo $8 .^{\circ}, \mathrm{n} .{ }^{\circ} 2$ e 3.

73 Ao abrigo do disposto no artigo $18 .^{\circ}, n .^{\circ} 3$.

$74 \mathrm{O}$ artigo $9^{\circ}$, da Lei n. ${ }^{\circ}$ 5/2008, de 12 de Fevereiro, estabelece o seguinte: "Antes da recolha da amostra, o sujeito passivo da colheita goza do direito de informação, previsto no 
No caso de indivíduo cego, surdo, mudo, analfabeto, desconhecedor da língua portuguesa, menor de 21 anos, ou se suscitar a questão da sua inimputabilidade ou da sua imputabilidade diminuída que impeça a cabal compreensão do acto, deve ser solicitado ao Tribunal a nomeação de defensor e, se necessário, tradutor para acompanhar a colheita ${ }^{75}$.

Não é realizada a recolha em caso de recusa do fornecimento dos dados ou documentos previstos no $n^{\circ} 2$ do artigo $6^{\circ}$ do Regulamento ${ }^{76}$ (excepto no que se refere à fotografia) ou recusa de autorização de recolha da amostra biológica. Nas situações anteriores, comunica-se por escrito tal facto à entidade requisitante, após obtenção de declaração do examinado ou, não sendo possível, de duas testemunhas.

n. ${ }^{\circ} 1$ do artigo $10 .{ }^{\circ}$ da Lei da Protecção de Dados Pessoais, com as necessárias adaptações, devendo ser informado, por escrito, nomeadamente:

a) De que os seus dados pessoais vão ser inseridos num ficheiro de dados pessoais, com excepção dos dados relativos às pessoas referidas no $n .^{\circ} 1$ do artigo $8 .^{\circ}$;

b) Sobre a natureza dos dados que são extraídos da amostra, isto é, o perfil de ADN;

c) De que o perfil de ADN é, nos casos admitidos na presente lei, integrado num ficheiro de perfis de ADN, com excepção dos dados relativos às pessoas referidas no n. 1 do artigo 8. ;

d) Da possibilidade de cruzamento do perfil recolhido com os existentes na base de dados de perfis de ADN, com menção expressa da possibilidade de utilização dos dados para fins de investigação criminal, quando aplicável;

e) De que a amostra recolhida pode ser conservada num biobanco, nos casos admitidos na presente lei."

75 Nos termos do artigo $64^{\circ}$, n. $^{\circ} 1$, alínea d), do Código de Processo Penal.

76 "A confirmação da autenticidade da identificação é realizada mediante apresentação de documento de identificação, do qual é feita cópia a integrar no processo, mediante recolha da impressão digital, e fotografia para a qual tenha sido previamente solicitado o consentimento."
Independentemente da constatação da inexistência de consenso na doutrina e na jurisprudência no que se refere à coercibilidade da recolha e inserção dos perfis de ADN na base de dados, designadamente no que diz respeito à aplicação dos artigos $172^{\circ}$, n. ${ }^{\circ} 1$ e $2^{77}$ (que remete para o artigo $154^{\circ}$, n. $^{\circ} 3^{78}$, e artigo $156^{\circ}$, n. ${ }^{\circ} 6$ e $7^{79}$ ) do Código de Processo Penal, o INML cumpre a determinação judicial que Ihe for apresentada. Pronunciaram-se sobre a questão da coercibilidade, sem posições consensuais, entre outros juristas, Paulo Pinto de Albuquerque ${ }^{80}$, Sónia Fidalgo ${ }^{81}$, Maria do Carmo S. Dias ${ }^{82}$, Benjamim

77 Artigo $172^{\circ}$ do CPP. Sujeição a exame.

1 - Se alguém pretender eximir-se ou obstar a qualquer exame devido ou a facultar coisa que deva ser examinada, pode ser compelido por decisão da autoridade judiciária competente.

2-É correspondentemente aplicável o disposto no n 3 do artigo $154^{\circ}$ e nos $n^{\circ} 6$ e 7 do artigo $156^{\circ}$.

78 Artigo $154^{\circ}$ do CPP. Despacho que ordena a perícia.

3 - Quando se tratar de perícia sobre características físicas ou psíquicas de pessoa que não haja prestado consentimento, o despacho previsto no número anterior é da competência do juiz, que pondera a necessidade da sua realização, tendo em conta o direito à integridade pessoal e à reserva da intimidade do visado.

79 Artigo $156^{\circ}$ do CPP. Procedimento.

6 - As perícias referidas no $n^{\circ} 3$ do artigo $154^{\circ}$ são realizadas por médico ou outra pessoa legalmente autorizada e não podem criar perigo para a saúde do visado.

7 - Quando se tratar de análises de sangue ou de outras células corporais, os exames efectuados e as amostras recolhidas só podem ser utilizados no processo em curso ou em outro já instaurado, devendo ser destruídos, mediante despacho do juiz, logo que não sejam necessários.

80 Comentário do Código de Processo Penal à luz da Constituição da República e da Convenção Europeia dos Direitos do Homem, cit., p. 463.

81 Determinação do perfil genético como meio de prova em processo penal», RPCC, Ano 16. ${ }^{\circ}$ N N. ${ }^{\circ}$, Janeiro-Março 2006, p. 135 e (nota 74).

82 Particularidades da prova em processo penal. Algumas questões ligadas à prova pericial, RCEJ, N. ${ }^{\circ} 3-2 .^{\circ}$ Semestre 2005, p. 211. 
da Silva Rodrigues ${ }^{83}$, Inês Torgal Pedroso da Silva ${ }^{84}$, Artur Pereira ${ }^{85}$, Tiago Caiado Milheiro ${ }^{86}$ e Jorge Reis Bravo ${ }^{87}$. A jurisprudência divide-se também quanto a este aspecto, designadamente tendo em consideração as diferentes formulações seguidas no n. ${ }^{\circ} 1$ e no.$^{\circ} 2$ do artigo $8 .^{\circ}$ da Lei n. ${ }^{\circ}$ 5/2008 (acórdãos do Tribunal da Relação do Porto de $10.12 .2008^{88}$ e de 10.07.201389, do Tribunal da Relação de Évora de 16.12.200890

83 Da Prova Penal T. I - A Prova Científica: Exames, Análises ou Perícias de ADN? Controlo de Velocidade, Álcool e Substâncias Psicotrópicas (à luz do Paradigma da Ponderação Constitucional Codificado em Matéria de Intervenção no Corpo Humano, face ao Direito à Autodeterminação Corporal e à Autodeterminação Informacional Genética), 3. ${ }^{a}$ Ed. revista, actualizada e aumentada, Rei dos Livros, Lisboa, 2010, pp. 546-547.

84 A (i)legitimidade da colheita coerciva de ADN para efeitos de constituição da base de dados genéticos com finalidades de investigação criminal», Lex Medicinae - Revista Portuguesa de Direito da Saúde - Ano 8, N.ํ 15, 2011, p. 178.

85 Da Prova. Âmbito, Especificidades e Valor Probatório», Genética Forense - Perspectivas de Identificação Genética (MARIA DE FÁTIMA PINHEIRO Coord.), Ed. Universidade Fernando Pessoa, Porto, 2010, p. 406 (nota 106).

86 Prova por ADN e o papel do Juiz de Instrução Criminal. Participação no Curso de Especialização "Temas de Direito Penal e Processual Penal". Centro de Estudos Judiciários - Lisboa, 6 de junho de 2014.

87 I. O aprofundamento da cooperação transnacional em matéria de intercâmbio de prova genética

II. A ordem de recolha de amostras em condenados, para análise e inserção na Base de Dados de Perfis de ADN. Abordagens preliminares. Encontro de trabalho. Conselho de Fiscalização da Base de Dados de Perfis de ADN -Procuradora-Geral da República e P. G. Distritais. Aspetos Práticos e Teóricos do Funcionamento da Base de Dados de ADN e da Obtenção da Prova por ADN em Processo Penal. Coimbra, 07 de março de 2014.

88 Relatora Juíza Desembargadora Maria Elisa da Silva Marques Matos Silva.

89 Relator Juiz Desembargador Joaquim Correia Gomes.

90 Relator Juiz Desembargador Alberto João Borges. e de 13.12.201191 e os Acórdãos do Tribunal Constitucional n. ${ }^{\circ}$ 155/200792 e 228/200793).

Se for determinado o uso da força para a realização da recolha da amostra biológica efectuada pelo INML é solicitado à entidade requisitante que convoque órgão de polícia criminal, força de segurança ou prisional para acompanhar a recolha.

A recolha de amostras em pessoas é feita em duplicado, através de raspado de células da mucosa bucal. Está excluída a possibilidade de colheita através de método invasivo, designadamente por punção venosa ou picada capilar ${ }^{94}$, como é usual no âmbito da rotina pericial de muitos laboratórios forenses. Sempre que possível e nos casos previstos na lei deve ser conservada uma parte da amostra que permita a realização de uma contra-análise.

As amostras referência são enviadas para o laboratório que determinará o perfil de ADN preferencialmente em mão ou, em situações excepcionais, por correio, acondicionadas em embalagem de violação detectável. A garantia da

91 Relator Juiz Desembargador Alberto João Borges.

92 De 10.04.2007, relator Juiz Conselheiro Gil Galvão (acórdão anterior à revisão do Código de Processo Penal de 2007).

93 De 28.03.2007, relatora Juíza Conselheira Maria Fernanda Palma (acórdão anterior à revisão do Código de Processo Penal de 2007).

94 Note-se, contudo, o acórdão do TC n. ${ }^{\circ}$ 155/2007: «Na verdade, a introdução no interior da boca do arguido, contra a sua vontade expressa, de um instrumento (zaragatoa bucal) destinado a recolher uma substância corporal (no caso, saliva), ainda que não lesiva ou atentatória da sua saúde, não deixa de constituir uma "intromissão para além das fronteiras delimitadas pela pele ou pelos músculos" [...], uma entrada no interior do corpo do arguido e, portanto, não pode deixar de ser compreendida como uma invasão da sua integridade física, abrangida pelo âmbito constitucionalmente protegido do artigo $25^{\circ}$ da Constituição.» 
cadeia de custódia da amostra é pressuposto para a inserção dos respectivos perfil e dados pessoais na base de dados.

As análises são realizadas em duplicado, sempre que possível, por profissionais diferentes, utilizando kits de amplificação diversos. No caso de amostras problema poderão ser inseridos perfis de mistura (correspondendo no máximo a dois indivíduos).

Após a análise, o laboratório prepara duas mensagens devidamente identificadas com o número do processo do serviço e o tipo de informação:

- uma com um anexo que contém o perfil de ADN;

- outra com um anexo que contém os respectivos dados pessoais ${ }^{95}$.

As mensagens são encriptadas e enviadas por correio electrónico para um designado Ficheiro Intermédio que se encontra na Sede do INML.

O Ficheiro Intermédio atribui uma codificação que permite relacionar as mensagens, sendo a única entidade que o consegue fazer. De imediato entrega em mão, em suporte digital, as duas mensagens encriptadas, do seguinte modo:

- a mensagem com os dados pessoais ao Ficheiro dos Dados Pessoais;

- a mensagem com o perfil de ADN ao Ficheiro dos Perfis de ADN.

95 Cópia do documento de identificação, cópia da fotografia, cópia da impressão digital, cópia do despacho do Tribunal, cópia do Auto de Colheita e, caso necessário, cópia do Auto de Recepção do laboratório que realiza o exame, bem como outros dados relevantes do processo.
Cada um dos dois grupos, constituídos por profissionais diferentes e em locais distintos, procede à desencriptação da respectiva mensagem e à inserção no respectivo ficheiro. Posteriormente imprimem o recibo confirmativo da inserção, que entregam ao Ficheiro Intermédio, e eliminam os anexos recebidos.

Após a recepção dos dois recibos confirmativos das duas inserções, os responsáveis pelo Ficheiro Intermédio enviam uma mensagem confirmativa da inserção com sucesso ao respectivo laboratório.

O laboratório procede à destruição da amostra presente no suporte inicial bem como de todos os seus derivados (no caso de voluntário ou condenado) e envia a respectiva confirmação de destruição para o Ficheiro Intermédio, dando-se por encerrado o processo.

Ocorrendo uma concordância, entre o perfil que está a ser inserido e um outro já existente na base de dados, a equipa do Ficheiro dos Perfis de ADN remete aos responsáveis pelo Ficheiro Intermédio os dois (ou eventualmente mais) códigos referentes aos perfis entre os quais se verificou a concordância. A partir desses códigos o Ficheiro Intermédio localiza os correspondentes identificadores dos dados pessoais, solicitando à equipa do Ficheiro dos Dados Pessoais que Ihe seja remetida a respectiva identificação do(s) processo(s). A indicação da existência de uma concordância é comunicada ao(s) tribunal(ais) respectivo(s), referindo-se que, nos termos do artigo $19 .^{\circ} \mathrm{da}$ lei n. ${ }^{\circ}$ 5/2008, os dados são comunicados ao juiz competente. 
O valor a pagar pela realização das perícias encontra-se previsto na tabela ${ }^{96}$ de preços das perícias forenses ${ }^{97}$.

Os procedimentos acima relatados de forma sucinta encontram-se pormenorizadamente detalhados no referido manual que serve de orientação aos diversos profissionais que integram os distintos ficheiros. Salienta-se que, apesar das elevadas normas de segurança, o processo decorre de forma célere, pois cada grupo sabe exactamente os procedimentos que lhe estão atribuídos.

\subsection{PROGRAMA INFORMÁTICO}

Foram perspectivadas três alternativas na escolha do programa informático que pudesse suportar a criação e o funcionamento da base de dados de perfis de ADN em Portugal: o desenvolvimento de um programa próprio por parte do INML, a compra do programa utilizado pelo Forensic Science Service do Reino Unido ou a aceitação da disponibilização do programa CODIS (Combined DNA Index System) usado pelo FBI nos Estados Unidos.

96 Actualmente encontra-se em vigor a tabela aprovada pela Portaria n. ${ }^{\circ}$ 175/2011, de 28 de Abril.

97 Actualmente o valor a pagar pela identificação genética individual em amostra referência no âmbito da base de dados de perfis de ADN (por pessoa) é de 2 UC, quando requerida por tribunais, e $4 \cup C$, quando requerida por outras entidades públicas ou privadas.

A investigação biológica de vestígios criminais incluindo a identificação genética de vestígios no âmbito da base de dados de perfis de ADN, por amostra e em função da sua natureza: a) De complexidade muito reduzida - $3 \cup C$; b) De complexidade reduzida - 4 UC; c) De complexidade média - 5 UC; d) De complexidade elevada - 6 UC; e) De complexidade muito elevada -7 UC.

O valor da unidade de conta é actualmente de 102 euros.
O desenvolvimento de um programa próprio por parte do INML necessitaria do envolvimento de recursos humanos da área da informática por tempo prolongado. Não se possuía tempo para essa opção, pois após a publicação da lei não se poderia aguardar um período de tempo cuja duração não foi possível perspectivar com segurança, mas que poderia ultrapassar um ou dois anos. Não se possuíam os recursos humanos para tal, pelo que seria necessária a contratação externa, com custos elevados. Além disso, seria uma aposta num programa sem quaisquer garantias de que funcionaria de forma segura e no pleno cumprimento dos pressupostos da lei. A hipótese do desenvolvimento de um programa próprio foi, por isso, afastada.

Elementos do Forensic Science Service deslocaram-se, por diversas vezes, ao INML com a intenção de disponibilizar o seu programa para funcionamento da base de dados Portuguesa. Apesar de ser um programa de grande qualidade e de ter dado anteriormente provas de segurança e bom funcionamento, não foi apresentada ao INML a garantia de que poderia ser adaptável à legislação nacional nem que poderia satisfazer os requisitos necessários à partilha de dados no âmbito do Tratado de Prüm, ao qual Portugal tinha já manifestado intenção de aderir. Além disso, era um programa de custos elevados. Foi também afastada a hipótese de aquisição deste programa.

O programa CODIS utilizado pelo FBI tinha já dado provas da sua segurança e bom funcionamento. Era usado não apenas nos Estados Unidos mas também por diversos países europeus, entre as quais a vizinha Espanha, país com o qual se perspectivava a maior necessidade de cooperação internacional na partilha de perfis 
de ADN. Por tal circunstância, e no âmbito do referido Tratado de Prüm, tinha sido desenvolvida uma plataforma que permite fazer a ligação aos países que tivessem as suas bases de dados de perfis de ADN instaladas no CODIS, plataforma que já tinha sido testada com êxito. Além disso, o LPC possuía já uma base de dados de perfis de ADN não identificados relativos a amostras problema, inseridos numa versão anterior do programa CODIS, cuja informação seria útil fazer transitar para a base de dados criada pela Lei n. ${ }^{\circ}$ 5/2008. Seria da maior relevância não desperdiçar todo o trabalho que havia anteriormente sido desenvolvido pelo LPC. Por último, o FBI disponibilizou-se a facultar o programa informático gratuitamente, instalá-lo, adaptá-lo à legislação nacional, dar formação aos especialistas Portugueses e dar todo o apoio que viesse a ser necessário. Face a estes motivos e após ter sido obtida a garantia por parte de especialistas informáticos nacionais de que estaria completamente assegurada a soberania nacional relativamente às informações presentes na base de dados a criar, foi aceite esta última alternativa $^{98}$.

\subsection{RESULTADOS}

Os quadros seguintes apresentam os resultados obtidos na base de dados Portuguesa em 14.07.2014:

98 Acrescente-se que, passados quatro anos sobre a entrada em funcionamento da base de dados, mantemos a convicção de que foi a opção mais correcta.

\begin{tabular}{|l|c|}
\hline Art. 15. $^{\circ}$ da Lei 5/2008 & TOTAIS \\
\hline a) Voluntários & $\mathbf{4}$ \\
\hline b1) Am. Prob. - Id. Civil & $\mathbf{4}$ \\
\hline b2) Am. Prob. (mist.) - Id. Civil & $\mathbf{0}$ \\
\hline c1) Am. Ref. - Pes. Des. - Id. Civil & $\mathbf{1}$ \\
\hline c2) Am. Ref. - Fam. Pes. & $\mathbf{1 2}$ \\
Des. - Id. Civil & $\mathbf{1 7 7 8}$ \\
\hline d1) Am. Prob. - Inv. Criminal & $\mathbf{3}$ \\
\hline d2) Am. Prob. (mist.) - Inv. Criminal & $\mathbf{2 5 7 2}$ \\
\hline e) Condenados & $\mathbf{1 0 5}$ \\
\hline f) Profissionais & $\mathbf{4 4 7 9}$ \\
\cline { 2 - 2 }
\end{tabular}

Pedidos de cooperação internacional:

\begin{tabular}{|ll|}
\hline TOTAIS & \\
\hline N. ${ }^{\circ}$ Pedidos: & 98 \\
\hline N. ${ }^{\circ}$ Perfis: & 200 \\
\hline N. ${ }^{\circ}$ Países: & 27 \\
\hline
\end{tabular}

Hits registados no CODIS

(AP: amostra problema; Cond: condenado):

\begin{tabular}{|lll|}
\hline Total & AP-AP & AP-Cond \\
\hline 155 & 130 & 25 \\
\hline
\end{tabular}

\section{COOPERAÇÃO INTERNACIONAL}

Considerando o carácter transfronteiriço de diversos tipos de criminalidade, bem como a inevitabilidade de cooperação policial e judiciária em matéria penal, foi sentida a necessidade de promover a partilha de dados entre diferentes estados membros.

Várias propostas foram discutidas no sentido de ser criada uma base de dados europeia, que 
apoiasse a investigação criminal entre os seus diversos países. O Programa de Haia para o reforço da liberdade, da segurança e da justiça, estabeleceu que apenas se justificariam novas bases de dados centralizadas europeias desde que representassem vantagens acrescidas.

Em 27 de Maio de 2005 foi assinado o Tratado de Prüm ${ }^{99}$, relativo ao aprofundamento da cooperação transfronteiras, em particular no domínio da luta contra o terrorismo, a criminalidade transfronteiras e a migração ilegal.

Tendo sido discutida a proposta de criação de uma base de dados europeia em reuniões de peritos de ADN no âmbito do Tratado de Prüm, defendemos a posição de que a partilha de dados entre as bases de dados dos diversos países permitiria as vantagens de uma única base de dados centralizada, sem os inconvenientes resultantes dos receios da perda de controlo de dados de cidadãos nacionais. Ou seja, é possível a obtenção da informação útil relativa a coincidência de perfis de ADN oriundos de diferentes países, mantendo-se em cada estado membro os dados pessoais relativos aos seus cidadãos (nome, morada, condenações anteriores, etc.). Foi esse o sentido da Decisão 2008/615/JAl do Conselho da União Europeia, de 23 de Junho de 2008, relativa ao aprofundamento da cooperação transfronteiras, em particular no domínio da luta contra o terrorismo e a criminalidade transfronteiras. Tal decisão, que veio alargar o âmbito do Tratado de Prüm, define regras de responsabilização sobre a segurança dos dados armazenados, bem como critérios de protecção dos dados pessoais. Prevê ainda uma partilha, célere e eficaz, de dados relativos a

99 Entre a Bélgica, a Alemanha, a Espanha, a França, o Luxemburgo, a Holanda e a Áustria. identificação dactiloscópica, a registo de matrícula de veículos, além de perfis de ADN, entre estados membros. Estabelece normas relativas às condições de transmissão de dados relacionados com determinados eventos de alcance transfronteiriço, bem como normas relativas ao aprofundamento da cooperação policial transfronteiras.

A Decisão 2008/615/JAl estabelece que os estados membros devem assegurar a disponibilidade, para comparação, dos perfis de ADN contidos nas respectivas bases de dados. Refere o diploma que as bases de dados deverão conter apenas "os perfis de ADN obtidos a partir da parte não codificante do ADN". Reforça-se assim um aspecto de extrema relevância social e que tem sempre merecido referência em diplomas anteriores relativos às bases de dados de perfis de ADN.

Tal decisão permite, nos termos do seu artigo 3. ${ }^{\circ}$, a consulta automatizada de perfis de ADN, mediante a comparação entre um perfil concreto e os perfis constantes das diversas bases de dados. Pode haver a comparação entre um perfil de ADN relativo a uma amostra problema e os perfis de amostras referência ou perfis de amostras problema constantes nas bases de dados dos distintos países. Mas também pode haver a comparação entre um perfil de ADN relativo a uma amostra referência e os perfis de amostras problema que estão nas diversas bases de dados. A consulta permite a constatação de coincidência ou não coincidência entre perfis de ADN, mediante a transmissão de uma resposta automática.

A decisão permite também, de acordo com o seu artigo $4 .^{\circ}$, uma comparação automatizada de perfis de ADN. Um estado membro poderá enviar o conjunto dos seus perfis de ADN não identificados para comparação com os perfis de outros países, se 
tal for admissível na legislação do estado membro requerente. A comparação poderá ser efectuada com os perfis identificados e com os perfis não identificados do país requerido. Uma vez mais se refere que a circunstância de ser obtida uma coincidência entre um perfil de ADN não identificado de um país requerente com um perfil também não identificado de um país requerido poderá ser de extrema utilidade para um processo de investigação criminal, apesar de não ser possível a identificação imediata da pessoa envolvida.

Estes processos ocorrem através dos pontos de contacto nacionais para o efeito designados. No que se refere aos perfis de ADN, o ponto de contacto nacional designado pelo Ministério da Justiça Português foi o INML.

Existindo uma coincidência, numa segunda fase poderão ser solicitados os correspondentes dados pessoais específicos relativos a um cidadão de um outro estado membro ou outras informações relacionadas, sendo transmitido apenas o que for permitido pela legislação nacional do país requerido. A Decisão 2008/615/JAl estabelece um conjunto de pressupostos e obrigações no que se refere à transmissão de dados pessoais entre os estados membros, no sentido de salvaguardar a correcta utilização e a segurança dos dados.

A decisão permite ainda que se proceda à colheita de material biológico a uma pessoa que se encontre no território de um estado membro requerido e que este realize a respectiva análise laboratorial, obtendo e enviando o perfil de ADN obtido. Esta possibilidade está dependente do estabelecido nas legislações dos estados membros requerentes e requeridos.

Também no dia 23 de Junho de 2008 foi aprovada a Decisão 2008/616/JAI do Conselho da
União Europeia, referente à execução da Decisão 2008/615/JAl, estabelecendo um conjunto de normas relativas à execução de natureza administrativa e de natureza técnica desta decisão. É estabelecido que as redes de comunicações utilizadas para efeitos de transmissão de dados são os Serviços Telemáticos Transeuropeus Seguros entre Administrações (Testa II) e as respectivas versões mais recentes. É também fixado que os estados membros deverão tomar as providências necessárias para que possa ser assegurada a possibilidade de consulta ou de comparação automatizada de dados a qualquer hora do dia, nos sete dias da semana. São definidos os dados que podem ser enviados no âmbito dos pedidos de consulta ou comparação automatizada.

Quanto aos marcadores a analisar, os perfis de ADN enviados ou disponibilizados para efeitos de consulta ou comparação deverão incluir pelo menos 6 dos 7 marcadores previstos no European Standard Set (ESS) ou no Conjunto Normalizado de Loci da Interpol (ISSOL), entre os 24 utilizados pela Interpol. Não são admitidos perfis de mistura no intercâmbio de dados. As regras concretas de inclusão, de concordância e de notificação são definidas no anexo à Decisão 2008/616/JAl.

O prazo de execução para a produção de efeitos das decisões 2008/615/JAl e 2008/616/JAI, de 23 de Junho de 2008, foi fixado em três anos após a sua entrada em vigor ${ }^{100}$. Apesar de Portugal ter sido um dos últimos países da União Europeia a ver aprovada legislação que permitisse a criação de uma base de dados de perfis de ADN, foi um dos poucos estados membros a conseguir cumprir,

100 Vinte dias após a sua publicação no Jornal Oficial da União Europeia, que ocorreu em 6 de Agosto de 2008. 
dentro do prazo, as exigências estabelecidas nas citadas decisões europeias.

Após a preparação necessária e a realização dos testes indicados, o INML respondeu ao questionário sobre protecção de dados e ao questionário sobre intercâmbio de dados de $A D N^{101}$, realizou com êxito o ensaio-piloto e solicitou ${ }^{102}$, como estabelecido na decisão, a visita de avaliação por um dos estados membros que já tivesse iniciado a aplicação da decisão. A visita foi realizada por um grupo de peritos alemães ${ }^{103}$ que aprovou de imediato o funcionamento da base de dados Portuguesa e as normas de segurança criadas, não tendo sido necessária qualquer outra visita de avaliação. O relatório de avaliação salientou a qualidade das medidas de segurança existentes na base de dados Portuguesa ${ }^{104}$. Nessa sequência, foi aprovada a Decisão do Conselho de 19 de Julho de 2011 "relativa ao lançamento do intercâmbio automatizado de dados de ADN em Portugal"105. Na decisão ficou expresso que "... Portugal aplicou integralmente as disposições

101 Nos termos do artigo 20. ${ }^{\circ}$ da Decisão 2008/616/JAI.

102 No início de 2011.

103 Jimmy Wang, Martin Eckert e Alexander Bachmann.

104 Conclusões do relatório: "The implementation of the Prüm DNA application and the related Prüm DNA information flow both on a legislative level and a technical level has been concluded successfully in Portugal. Portuguese DNA labs and database have methodical and sophisticated work flows showing excellent quality assurance measures. Based on the evaluation team's observations, the DAPIX group should recommend to the Council that for the purposes of automated searching of DNA data, Portugal has fully implemented the general provisions of Council Decision 2008/615/JHA and Council Decision 2008/616/JHA. Portugal is also entitled to receive and supply personal data pursuant to Article 5 of Council Decision 2008/615/JHA. Wiesbaden. 23rd May 2011."

105 Publicada no Jornal Oficial da União Europeia em 27 de Agosto de 2011. gerais relativas à protecção de dados previstas no capítulo 6 da Decisão 2008/615/JAl, estando habilitado a receber e a transmitir dados pessoais nos termos dos artigos 3. ${ }^{\circ}$ e $4 .^{\circ}$ dessa decisão...". O Conselho de Fiscalização à data em funções entendeu que o INML não poderia dar início à partilha de perfis de ADN sem uma "transposição" ou "adequação" da Decisão 2008/615/ $\mathrm{JAI}$, pelo que foram solicitadas ao Ministério da Justiça orientações no sentido de ser tomada uma decisão quanto a este assunto. Defenderam essa posição Simas Santos ${ }^{106}$ e Helena Moniz ${ }^{107}$, membros do referido Conselho de Fiscalização; Jorge Reis Bravo ${ }^{108}$ manifestou entendimento diferente.

106 "Mecanismos de verificação e Fiscalização (na Base de dados de Perfis de ADN)", A Base de Dados de Perfis de DNA em Portugal (Actas das Conferências CNECV em 13 de abril de 2012 em Coimbra), Coleção Bioética, 15, Conselho Nacional de Ética para as Ciências da Vida, Lisboa, 2012, p. 75.

107 "Condições e Limites da Utilização da Prova por ADN em Processo Penal (a Lei n. 5/2008)", A Base de Dados de Perfis de DNA em Portugal (Actas das Conferências CNECV em 13 de abril de 2012 em Coimbra), Coleção Bioética, 15, Conselho Nacional de Ética para as Ciências da Vida, Lisboa, 2012, p. 81.

108 "I. O aprofundamento da cooperação transnacional em matéria de intercâmbio de prova genética

II. A ordem de recolha de amostras em condenados, para análise e inserção na Base de Dados de Perfis de ADN. Abordagens preliminares. Encontro de trabalho. Conselho de Fiscalização da Base de Dados de Perfis de ADN -Procuradora-Geral da República e P. G. Distritais. Aspetos Práticos e Teóricos do Funcionamento da Base de Dados de ADN e da Obtenção da Prova por ADN em Processo Penal. Coimbra, 07 de março de 2014.

Art. 7. [da Decisão 2008/615/JAl] (Recolha do material genético e transmissão de perfis de ADN): nesse particular, parece resultar evidente a necessidade de adoção de algumas medidas de execução do preceito, que terá de ser necessariamente «regulamentado», nomeadamente quanto à determinação dos critérios de aplicação do seu regime, v.g., a definição dos órgãos judiciários competentes — em razão da hierarquia e do território - para proceder às diligências de prova requeridas, a previsão da disciplina procedimental, o eventual regime de recursos, definir se o perfil ficará a constar na base de dados nacional, entre outros aspetos. 
Tendo sido assinado um acordo entre Portugal e os Estados Unidos da América para reforçar a cooperação no domínio da prevenção e do combate ao crime ${ }^{109}$, aprovado também pela Assembleia da República ${ }^{110}$, com vista à possibilidade de partilha de perfis de ADN, entre outros dados, em moldes similares aos estabelecidos na Decisão 2008/615/ JAI do Conselho da União Europeia, de 23 de Junho de 2008, o INML tem aguardado a disponibilidade dos EUA para dar início aos testes técnicos.

\section{CONSIDERAÇÕES FINAIS}

A criação da base de dados de perfis de ADN constituiu um marco importante para as Ciências Forenses Portuguesas. Instrumento imprescindível para a investigação criminal e a identificação civil nos países desenvolvidos, esta ferramenta possui potencialidades que importa valorizar. Contudo, a base de dados Portuguesa tem estado aquém das suas capacidades, sendo importante a discussão sobre os motivos que o justificam. O desconhecimento da Lei n. ${ }^{\circ}$ 5/2008 tem sido apontado como a principal razão para a inexistência de um maior número de despachos de inserção de perfis. Múltiplas iniciativas têm sido organizadas com vista a colmatar esse desconhecimento. O aumento progressivo do número de despachos de inserção de perfis parece corroborar essa constatação.

Portanto, em bom rigor, se bem vemos as coisas, a necessidade de mediação normativa mais relevante é exigida por uma matéria - obtenção e transmissão de prova genética - que não deveria integrar a DECISÃO 2008/615/ JAI, mas que nela se encontra prevista."

109 Assinado em Lisboa, em 30 de Junho de 2009.

110 Resolução da Assembleia da República n. 128/2011, de 31 de Agosto de 2011.

\section{BIBLIOGRAFIA}

AA. VV., (2012). A Base de dados de Perfis de DNA em Portugal: Actas das Conferências CNECV em 13 de abril de 2012 em Coimbra, Coleção Bioética, 15, Conselho Nacional de Ética para as Ciências da Vida, Lisboa.

De Albuquerque, P.P. (2009). Comentário do Código de Processo Penal à luz da Constituição da República e da Convenção Europeia dos Direitos do Homem, 3. ${ }^{a}$ Ed. actualizada, Universidade Católica Ed.

Bravo, J.D.R. (2010). Perfis de ADN de Arguidos-Condenados (O artigo 8. ${ }^{\circ}$, n. ${ }^{\circ} 2$ e 3, da Lei n. ${ }^{\circ}$ 5/2008, de 12-02), Revista Portuguesa de Ciência Criminal, 20(1), 97-126.

ENFSI survey on DNA databases in Europe, December 2013, published 11.04.2014: http://www.enfsi.eu/sites/default/ files/documents/enfsi_survey_on_dna_databases_in_europe_december_2013_1.pdf; acedido em 05.07.2014.

ENFSI report on DNA legislation in Europe, published 18.08.2012: http://www.enfsi.eu/sites/default/files/documents/enfsi_report_on_dna_legislation_in_europe_0. pdf; acedido em 05.07.2014.

Fidalgo, S. (2006). Determinação do perfil genético como meio de prova em processo penal. Revista Portuguesa de Ciência Criminal, 16(1), 115-148.

Moniz, H. (2002). Os problemas jurídico-criminais da criação de uma base de dados genética para fins criminais. Revista Portuguesa de Ciência Criminal, 12(2), 237-264.

Moniz, H. (2009). A base de dados de perfis de ADN para fins de identificação civil e criminal e a cooperação transfronteiriça em matéria de transferência de perfis de ADN. Revista Portuguesa de Ciência Criminal, 30(120), 145-156.

Neto, L. (2006). Sobre a existência e utilização de uma base de dados genética em Portugal, Homenagem ao Prof. Doutor André Gonçalves Pereira, Faculdade de Direito da Universidade de Lisboa, Coimbra Editora. 